\title{
The disempowerment of the judiciary in Syria since the March revolution of 2011 and the emergence of off-bench resistance to authoritarian rule: What role for women judges and prosecutors?
}

OÑATI SOCIO-LEGAL SERIES, FORTHCOMING: GENDER AND JUDGING IN THE MIDDLE EAST AND AFRICA DOI LINK: HTTPS://DOI.ORG/10.35295/OSLS.IISL/0000-0000-0000-1245

RECEIVED 19 SePtember 2019, ACCEPTED 07 NOVEMBER 2019, FiRst-OnLine Published 30 NOVEMBER 2021

\section{MONIQUE C. CARDINAL*}

\section{Abstract}

The Arab uprisings of 2010-2011 generated a growing movement for change among the judicial corps throughout the Arab world. Judges and prosecutors created independent associations in Morocco, Mauritania, Yemen, Libya, Lebanon, and Tunisia to represent their interests and promote a better administration of justice. Since the March Revolution of 2011 in Syria, members of the judiciary also attempted to create their own association, but failed to do so. This article briefly outlines the demographics of the judicial corps after ten years of conflict in Syria. A noticeable change is the increase in the number of women in the judiciary and their promotion to positions of power. How have women judges and prosecutors used the greater authority granted to them? To the advantage of the regime, as a means for self-promotion or to better defend the rights of all? The second part of the article details the progressive disempowerment of the judiciary, the expansion of the criminal justice system and the creation of the Counterterrorism Court used by the regime to quash the popular uprising. In the final section, stories of off-bench resistance highlight efforts made by judges and prosecutors to defend their judicial autonomy and the basic human rights and freedoms of all Syrians.

\section{Key words}

Syria; March Revolution; women; judges; prosecutors; criminal courts; off-bench resistance; Counterterrorism Court

\footnotetext{
* Associate professor at the Faculté de Théologie et de Sciences Religieuses, Université Laval (Canada), Pavillon Félix-Antoine-Savard, 2325 rue des Bibliothèques, Québec (QC), G1V 0A6. Dr. Cardinal's current research focuses on the teaching and practice of Islamic law in Syria. Email address: monique.cardinal@ftsr.ulaval.ca
} 


\section{Resumen}

Las protestas árabes de 2010-2011 generaron un creciente movimiento a favor del cambio entre los cuerpos judiciales en todo el mundo árabe. Surgieron asociaciones independientes de jueces y fiscales en Marruecos, Mauritania, Yemen, Libia, Líbano y Túnez, para representar sus intereses y promover una mejor administración de justicia. A partir de la revolución de marzo de 2011 de Siria, hubo intentos por parte de miembros de la judicatura para crear su propia asociación, pero fracasaron. Este artículo describe brevemente la demografía de los cuerpos judiciales después de diez años de conflicto en Siria. Un cambio perceptible consiste en el aumento del número de mujeres en la judicatura y su ascenso a puestos de mando. ¿Cómo han utilizado las juezas y fiscalas la mayor autoridad con que se las ha revestido? ¿En pro del régimen, como forma de promoción personal, o para defender mejor los derechos generales? La segunda parte del artículo detalla la pérdida progresiva de poder de la judicatura, la expansión del sistema de justicia penal y la creación del Tribunal Antiterrorista, utilizado por el régimen para aplastar el levantamiento popular. En la última sección, se aducen historias de resistencia al margen del juzgado por parte de jueces y fiscales, con el objeto de defender su autonomía judicial y los derechos y libertades básicos de todos los sirios.

\section{Palabras clave}

Siria; Revolución de Marzo; mujeres; juezas; fiscalas; juzgados de lo penal; resistencia al margen del juzgado; Tribunal Antiterrorista 


\section{Table of contents}

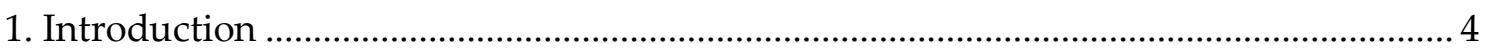

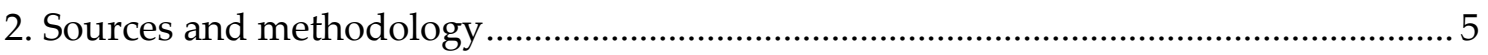

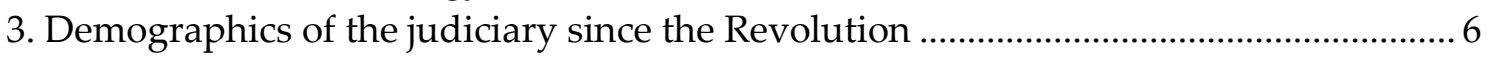

3.1. As the people suffer, so do their judges and prosecutors ........................................ 6

3.2. Women judges and prosecutors on the rise ......................................................... 7

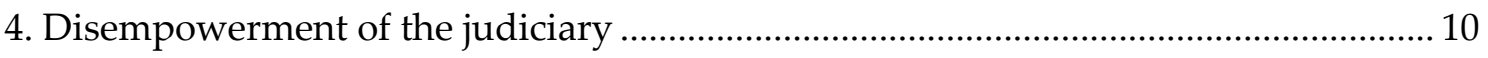

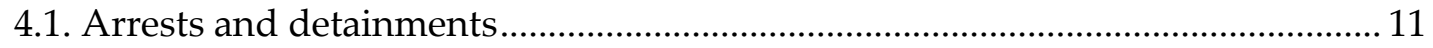

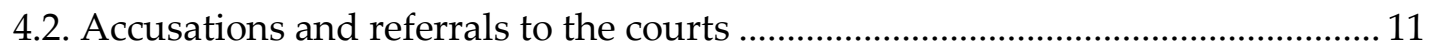

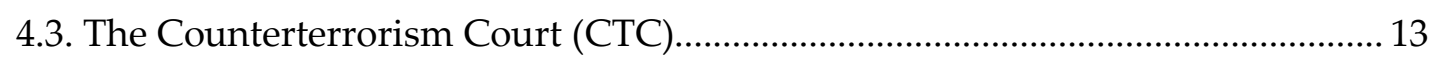

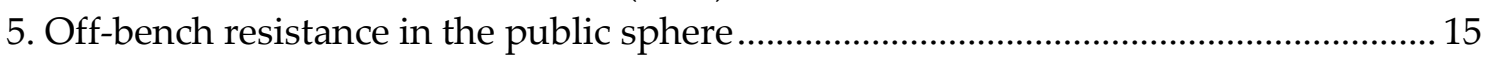

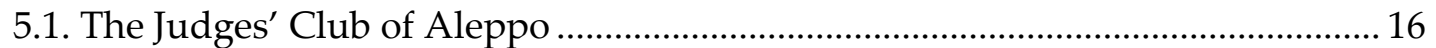

5.2. Investigations into suspicious deaths and public denunciation of the

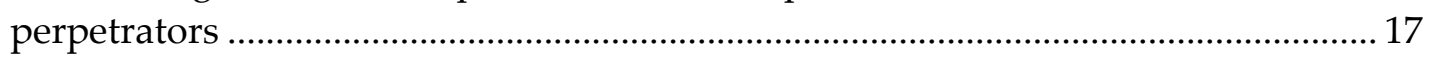

5.3. Judges and Prosecutors form associations and join the Syrian Opposition ....... 18

5.4. A woman judge defies a member of Parliament and the Minister of Justice, and becomes a victim of family connections and political power.............................. 19

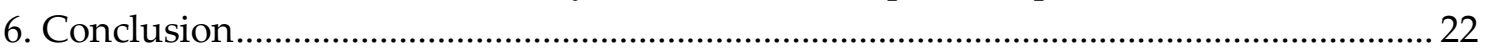

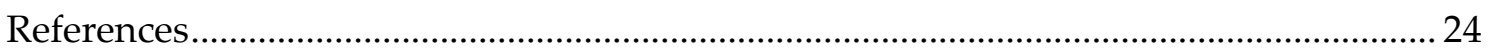

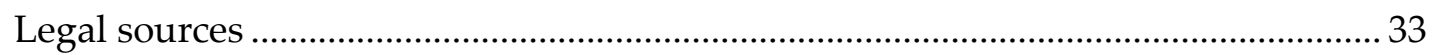

Decisions and decrees of judicial appointments and creation of courts .....................35 


\section{Introduction}

The Arab uprisings of 2010-2011 generated an unprecedented movement of civil protest when hundreds of thousands of people descended in the streets to demand basic social, economic, civil and political rights. The movement eventually intensified in response to the violent repression carried out by the police, army, security forces and militias of the different regimes which wanted to quell the protest and return people to their prerevolutionary submission and fear. In the case of Syria, the peaceful uprising turned into an armed conflict.

A growing movement for change also emerged among the judicial corps throughout the Arab world. Judges and prosecutors mobilised their efforts and organised themselves into new professional associations to represent their interests and promote judicial independence and a better administration of justice in their respective jurisdictions. Since 2011, clubs and associations of the judiciary were founded in Morocco, Mauritania, Yemen, Libya, Lebanon, and Tunisia, notably the Women's Association of Judges of Tunisia, the first all-female association of judges in the Arab world (Al-Shabbi ${ }^{1}$ 2016). ${ }^{2}$ This mobilisation of the judiciary culminated in the creation of a pan-Arab Union of Judges (AUJ), al-ittihāad al-'arabì l-il-quḍāt, on 22 September 2018 in Tunis. Judges and prosecutors of the newly founded associations in addition to members of the Palestinian Judges Association Club (created in 2010) and a delegate sent from Oman participated in the founding meeting (Al-Shantuf 2018). And since its creation, the Union periodically publishes communiqués which highlight issues relating to the violation of the immunity and independence of members of the judiciary. ${ }^{3}$ Another call for the creation of a professional association of judges independent of the State was published on a Facebook account and supported by a thousand Algerian judges in protest of the re-election of President Abdelaziz Bouteflika. On 11 March 2019, judges descended in the streets to join mass demonstrations against the re-election of Bouteflika for a fifth mandate and announced their refusal to oversee the presidential election scheduled for 18 April (France 24 and AFP 2019). Without a doubt, a profound transformation has come about in the Arab world. The call for dignity and human rights, as well as the spirit to resist the violation of these rights, now inhabit a new Arab citizenry and continue to fuel many of the ongoing movements and calls for reforms.

In Syria, judges and prosecutors from Aleppo formed a club to defend their interests in 2012, and other members of the judiciary from northern Syria who publicly declared their resignation from office and opposition to the regime also formed independent associations with the intention of offering services to the jurisdictions no longer under State control (more to follow). But soon, these associations were forced to seek refuge in Turkey when extremist opposition groups took control of the region and imposed their own "system of justice". Despite the inability of the judicial corps of Syria to establish an association which represents their interests, many members, whether they support or

\footnotetext{
${ }_{1}^{1}$ Partial diacritics are used to transliterate Arabic proper nouns and words.

2 Jam'īyat al-qādìy $\bar{a} t$ al-tūnsīyāt was founded on 8 October 2016. Two other judicial associations already exist in Tunisia: the Association des magistrats tunisiens (AMT) and the Syndicat des magistrats tunisiens (SMT). See Ghamroun 2016.

3 The website of the AUJ is at the following address: www.arabunionjudges.org. Since 2018, judicial associations of Sudan, Iraq and Algeria also joined the AUJ: http://arabunionjudges.org/?page id=30 [Access 18 June 2021].
} 
oppose the regime of Bashar al-Asad, have publicly or privately practiced a form of "offbench resistance" (Trochev and Ellett 2014) in an attempt to reassert their autonomy as individuals and professionals in a judicial system that became increasingly subservient to the executive power and its security forces as the March Revolution of 2011 progressed.

The first part of the article briefly outlines the demographics of the judicial corps after ten years of conflict in Syria. A noticeable change is the increase in the number of women in the judiciary and their promotion to positions of power. How have women judges and prosecutors used the greater authority granted to them? To the advantage of the regime, as a means for self-promotion or to better defend the rights of all (or a combination of the aforementioned)? The second part of the article details the progressive disempowerment of the judiciary from the outset of the 2011 March Revolution, and the creation of the Counterterrorism Court. Many judicial functions were transferred to state security officials, and matters normally submitted to the jurisdiction of the ordinary criminal courts were redirected to courts of exception: the military field courts and the new Counterterrorism Court. An in-depth analysis of court demographics before and after 2011 will demonstrate that the Syrian regime aggressively expanded the criminal justice system in order to systematically apply a politics of judicial repression to remain in power and control the wave of civilian protests (Ginsburg and Moustafa 2008). In the final section, stories of off-bench resistance will highlight new forms of judicial autonomy practiced by members of the judiciary such as the formation of social networks of support and the public denouncement through social media of the corruption and abuse of power by the executive and its security forces. These narratives allow the reader to better understand the inner workings of the judicial system and to realise how difficult it is for judges and prosecutors to defend basic human rights and freedoms of all Syrians when they are unable to exercise their judicial functions without the interference of the regime and its high-ranking officials.

\section{Sources and methodology}

The protest movements of the Arab world became known across the globe from the perspective of actors on the ground because people used the Internet to show and narrate events they were living. In the case of Syria, the regime had periodically interrupted Internet service prior to the March Revolution and blocked access to certain websites, but in February 2011, it decided to give full access to YouTube and Facebook (Preston 2011, Sinjab 2011). Certain critics claimed that this was done with the intention of monitoring Internet use in order to identify activists and potential opponents to the regime. Consequently, many young Syrians were arrested for making critical comments of a political and social nature, sharing photos, uploading videos of popular protests and the crackdown on those protests by security forces and the Syrian Arab army. A number of people were arrested to be later accused of "acts of terrorism" which undermined the authority of the State, national sentiment, and threatened public security. At the same time, the Syrian regime and its supporters used social media to propagate their own ideas and narratives of events. A state-sponsored group of hackers known as the Syrian Electronic Army launched attacks against websites which opposed the regime and were critical of the president. The proliferation of online sources, for and against the Syrian government, soon became a topic that warranted research in order to identify the actors 
of the "new media landscape" of Syria (Issa 2016). The Syrian regime had always tightly controlled national media outlets, but an independent media emerged online that provided new sources of information.

This article is a "desk research paper" because it is predominantly based on online sources. Of course, it is informed by the author's previous field work on the judiciary in Syria from 2004 to 2009. Interviews were conducted in Arabic with 122 women judges and prosecutors in the main courthouses throughout Syria. Since the Revolution of 2011, the author has been able to follow the careers of Syrian women judges and prosecutors to a certain degree from a distance, online, but she has never contacted any of them, first of all, to protect their anonymity, and second of all, not to put them in danger of possibly falling victim to false accusations of collaborating with foreign powers to undermine the State. A simple call or online contact could be used as a pretext by the intelligence agencies and security forces to detain a person.

Online sources used for this paper comprise Facebook and Twitter accounts, blog entries, online newspapers, magazines, and news outlets, videos published on YouTube, official websites of the Syrian government, notably the website and the Facebook account of the Ministry of Justice (MOJ). The MOJ Facebook account was set up in May 2017 and is an important source of legislative decrees and ministerial decisions for the appointments to the judiciary and the courts cited in this article. The author also consulted reports on events in Syria since the March Revolution of 2011 prepared by UN agencies, in particular the Independent International Commission of Inquiry on the Syrian Arab Republic, international NGOs such as Amnesty International and Human Rights Watch, and Syrian human rights monitoring groups such as the Violations Documentation Center (VDC), the Syrian Revolution Martyr Database, the Syrian Network for Human Rights and the Syrian Center for Policy Research. Online sources both for and against the Syrian regime were used in order to obtain as many facts as possible and understand the different points of view regarding the political conflict and the possibility for change.

\section{Demographics of the judiciary since the Revolution}

\subsection{As the people suffer, so do their judges and prosecutors}

Members of the judiciary, like all Syrians, have suffered displacement, economic hardships and death since the March Revolution of 2011. Over half of the pre-conflict population has been displaced with more than 6.1 million internally displaced and 5.6 million refugees settled in bordering countries (Office for the Coordination of Humanitarian Affairs - OCHA - 2020, 8). ${ }^{4}$ The Ministry of Justice has not published official statistics on the overall attrition of the judicial corps, but it must be important since the State can no longer simply recruit graduates of the Higher Institute of Judicial Studies in order to renew the judicial corps. Since 2012, the Ministry has organised a series of written and oral exams - many more than in the past - to recruit new judges from a pool of experienced lawyers who are then appointed to different levels of the courts. Though the overall numbers of the judiciary must fluctuate according to the

\footnotetext{
4 The Internal Displacement Monitoring Centre (Geneva) estimated that, as of April 2020, 6.5 million people were internally displaced in Syria (Internal Displacement Monitoring Centre - IDMC - 2020, 35).
} 
intensification of the armed conflict and the displacement of persons, the figure of 1,700 is often quoted in national media as the total number of judges and prosecutors (Hamiju 2016). It was reported in 2014 that about $60 \%$ of judges and prosecutors are displaced, rent apartments and are impoverished because of inflation (D-P News 2014). The Minister of Justice, Hisham al-Sha'ar, announced in June 2017 that 33 members of the judiciary were martyred since 2011 (Hamiju 2017a), and that members who had fled the armed conflict in order to survive could be reinstated on the condition that they had not resigned from public office and actively opposed the government. During the conflict, the government has continued to pay all civil servants, even in regions no longer under its control, provided they continue to support it. As state employees, the majority of judges and prosecutors of Syria are not financially independent and rely on their salaries for the livelihood of themselves and their families. Therefore, they are subservient to the State for their economic survival, and this could explain their overall compliance with the regime's interference in the justice system.

\subsection{Women judges and prosecutors on the rise}

In 2017, women made up 30\% of the judicial corps in Syria, a two-fold increase from the pre-revolutionary figure of 15\% (which amounted to 240 members, UN CEDAW 2012, 34). Syrian state media would like us to believe that the increase is due to government policy which aims to promote women's rights and gender equality in the legal professions (Hamiju 2017b). However, this claim is contradicted by hard facts. The number of women in the judiciary has increased progressively since the March Revolution of 2011 because men are vanishing: they are dead, detained, forcibly disappeared, fighting or displaced.

The majority of victims of the Syrian regime's war against civilians (Hubrecht 2017) are men: $88 \%$ of civilians (Syrian Revolution Martyr Database 2016$)^{5}$ according to one estimate; approximately 70\% according to a second (AFP 2018). As reported by another source, of the 99,479 persons forcibly disappeared between March 2011 and August 2020, 91.8\% were men (Syrian Network for Human Rights 2020, 8). And men's life expectancy has decreased drastically, from 69.7 years of age in 2010 to 48.2 years in 2014, predominantly among young adult males due to their involvement in fighting and their targeting by the regime. Women have fared better: their life expectancy declined by 10.1 \% from 72 years of age in 2010 to 64.8 years in 2014 (Syrian Center for Policy Research 2016, 64-65). More recent figures show an increase in life expectancy due to a decrease in the fighting: 59.4 years for men and 66.9 years for women in 2019 (Syrian Center for Policy Research 2020, 88). Nonetheless, male mortality remains extremely high: $82.2 \%$ of "conflict-related deaths, the majority of which were men of working age" (Ibid., 89). The latest figures of documented civilian deaths provided by the UN Office of the High Commissioner for Human Rights indicate that victims are overwhelmingly male. Of the 350,209 "identified individuals killed in the Syrian conflict between March 2011 to March 2021", 91,75\% were male adults and children (UN Office of the High Commissioner for

\footnotetext{
${ }^{5}$ According to the Syrian Revolution Martyr Database, 151,887 martyrs died up until April 30, 2016, 12\% of whom were women $(17,538)$ and $88 \%$ of whom were men $(134,349)$. These figures do not include government forces and pro-regime militias.
} 
Human Rights 2021, 1, 3, Table A3). ${ }^{6}$ With the progressive decrease of men, women have had to step in as heads of households and have gained access to formerly maledominated jobs (Hilton 2017). The third and most recent cohort to study at the Higher Institute of Judicial Studies comprises an unprecedented majority of women: 28 out of a total of 49 trainees (Decision No. 648L of 18 February 2021)..$^{7}$ It is foreseeable that one of the outcomes of the Syrian conflict will be the progressive feminisation of the judiciary.

To an unprecedented degree, women have attained positions of authority and responsibility in the judiciary. In 2017, one of the deputy ministers of Justice, the director of the Higher Institute of Judicial Studies, the head of the Judicial Inspections Department of the Ministry of Justice and the President of the First Chamber of the Counterterrorism Court were all women: respectively Sahar Akkash, Amina alShammat, Su'ad Kadib and Zahira Bashmani. Sahar Akkash, as deputy minister of Justice, and Su'ad Kadib, as chief of the Judicial Inspections Department, were also members of the High Judicial Council, the administrative body of the Ministry of Justice responsible for the appointment, promotion, transfer, discipline and removal of judges and prosecutors in Syria. Women thus became the head authorities regarding the recruitment of the judiciary, their training, and the evaluation and auditing of their performance. It is by their appointment to the Counterterrorism Court that women judges and prosecutors were granted a new type of power they had not experienced in the past.

In a show of political reform, the Syrian regime also introduced new laws in 2011 and 2014 to govern the electoral process. All elections - municipal, parliamentary and presidential -, and referenda were required by law to be monitored by members of the judiciary. ${ }^{8}$ Seven judges of the Court of Cassation were appointed by the High Judicial Council to the High Elections Committee which monitored the electoral process and reviewed complaints as well as voting irregularities during the elections. The High Elections Committee appointed judges and prosecutors to the district elections committees which oversaw the electoral process in each of the 14 governorates of Syria - though voting in Idlib, al-Raqqa and Deir Ezzor was transferred to neighboring governorates because of the fighting. At the outset, few women judges participated in the monitoring of elections, but progressively more of them were appointed to the committees. For example, Hasna al-Aswad, a senior-ranking judge of the Court of Cassation, was a member of the High Elections Committee which monitored the parliamentary elections in May 2012. For this election only one woman was appointed to a district committee: Abir Mundhir, a prosecutor in al-Suwayda, in southern Syria (General Organisation of Radio and TV - Syria - ORTAS - 2011). Two women judges of the Court of Cassation, Amina al-Shammat, as a regular member, and Munira Wasiti, as an alternate, were appointed to the High Elections Committee in 2014, which oversaw the parliamentary elections in April 2016 (Decree No. 133 of 24 April 2014); five women

\footnotetext{
${ }^{6}$ As mentioned in the OHCHR update, the figures provided do not reflect the real numbers of conflictrelated deaths. Only identifiable records, which comprise the full name of the deceased, the date and location of their death, are included.

7 See pictures of the swearing-in of the third cohort of the HIJS provided by SANA (Syrian Arab News Agency) on its Facebook account: Sana in Photos 2021.

${ }^{8}$ Legislative Decree No. 101 of 3 August 2011, and the General Elections Law No. 5 of 17 March 2014 which mandates the judicial oversight of presidential elections and referenda.
} 
judges were also appointed to district elections committees in $2016 .{ }^{9}$ Amina Shammat appeared in a number of news reports in Syrian state media explaining the judiciary's implication in the new electoral process and assuring the public that elections were fair, free and accessible to all and in accordance with the law (Khalaf 2016). Before the Revolution, this woman judge of more than 30 years of experience in civil law was highly respected by colleagues and personnel at the Damascus courthouse. It would appear that the regime wanted to capitalise on her good reputation by making her a spokesperson for the new elections process. Parliamentary elections were held in July 2020 under even worse conditions and with a weaker voter turnout (Abdel Nour 2020). Judges again were appointed to elections committees to oversee the voting process, but, at the end of the day, the judicial monitoring of elections is a cosmetic solution to a structurally-flawed electoral system that guarantees a Ba'th Party majority at the municipal and legislative levels. The Arab Socialist Ba'th Party came to power by a military coup d'état in 1963 and has remained the party in power ever since.

With regards to the presidential elections of 2014, changes to the nomination process allowed for multi-candidate presidential elections for the first time in Syria since the 1963 coup d'état. Applications were reviewed by the Supreme Constitutional Court. Two candidates ran against the incumbent president Bashar al-Asad: businessman and former Damascus parliamentarian, Hassan al-Nuri of the National Initiative for Administration and Change in Syria Party (established in 2012), and an independent originally from Aleppo and former communist, Mahir Abd al-Hajjar. Al-Asad was reelected by a majority vote of $88.7 \%$, while al-Nuri and al-Hajjar obtained respectively $4.3 \%$ and $3.2 \%$ of the votes; invalid or blank votes made up $3.8 \%$ of the votes (People's Assembly 2014). As stated by law, judges of the Supreme Constitutional Court monitored the voting and addressed any complaints about the presidential electoral process. For the first time, a woman was a member of the court: Jamila Muslim alSharbaji, a professor of constitutional law at Damascus University who obtained her doctorate in constitutional law from the Law Faculty of Cairo University in 2003. ${ }^{10}$ When the membership of the court was expanded to 11 members in 2014, a second woman was appointed to the court in 2018, the former chief of the Judicial Inspections Department, Salwa Kadib (Decree No. 165 of 8 May 2018; see SANA 2018). In addition to supervising the presidential elections, the Supreme Constitutional Court is also responsible for investigating and ruling on challenges regarding the validity of legislative elections, and deciding on the constitutionality of laws at the request of the president or a quarter of the members of the Syrian parliament. But as Syrian lawyers and judges point out, the Supreme Constitutional Court is subservient to the executive power, its members are appointed by the president, and the right to challenge state legislation is restricted to the president, the prime minister and members of parliament. In addition, since the March Revolution of 2011, not a single law that violates basic human rights and freedoms, such as the Counterterrorism Law of 2012, has been challenged before the court (Ali 2018).

\footnotetext{
9 Suzanne Sa'id (Samir 2016) and Muna Abd al-Karim in Tartus (Damas Times 2016); Ghada Nafuj and Amilda Hallaq in Homs (Television al-Khabar 2016), and Amal al-Shusha (executive member of the Ba'th Party) in Aleppo (Syrian Arab News Agency - SANA - 2016).

${ }^{10}$ Decree No. 173 of 22 May 2012, see Abu al-Zayn 2012; Page of the Faculty of Law of Damascus University, Teaching Staff. Available from: https://web.archive.org/web/20160708233959/http://damasuniv.edu.sy:80/ faculties/law/home/2009-03-26-11-17-23 [Access on 15 January 2021].
} 
The power of the judiciary to exercise any form of judicial review in Syria is basically non-existent. In fact, after the March Revolution of 2011, the power of the judiciary was systematically undermined by the regime and its security forces.

\section{Disempowerment of the judiciary}

In a show of political reform, Bashar al-Asad lifted the Emergency State Law which had been in place for almost half-a-century (Decree No. 161 of 21 April 2011). This law of 1962 (Legislative Decree No. 51 of 22 December 1962) had resulted in the permanent suspension of basic rights and freedoms, and had allowed the security forces and the military to use emergency powers to eliminate any opposition to the regime without judicial oversight. In addition, the Supreme State Security Court founded in 1968 was abolished (respectively Legislative Decree No. 47 of 28 March 1968, and Legislative Decree No. 53 of 21 April 2011); it had been instrumental in convicting political opponents and human rights defenders for four decades. All of these changes occurred within a month of the March Revolution on 21 April. Syria seemed to be on a new path towards restoring basic human rights and freedoms.

But what the State giveth the State taketh away. Two other legislative decrees also issued on 21 April restricted public demonstrations, prolonged periods of preliminary detention and granted police powers to other state officials. The full force of the State was mobilised to crush the popular protest.

Legislative Decree No. 54 restricted citizens' rights to associate and conduct demonstrations (Legislative Decree No. 54 of 21 April 2011). Procedures and authorisations were to be monitored by the Ministry of the Interior - reports soon emerged that authorisations were systematically denied and that security forces used the information to round up persons and detain them before demonstrations could even take place.

The second decree was an amendment to article 17 of the Criminal Code of Procedure of 1950 (Legislative Decree No. 112 of 13 March 1950). Legislative Decree No. 55 granted police powers to other state officials, notably personnel of the intelligence agencies and security forces, to detain, arrest and investigate persons suspected of a crime against the State and public security (articles 221, 260 to 339 and 388, 392 and 393 of the Criminal Code; Legislative Decree No. 55 of 21 April 2011). In addition, the amendment prolonged the legal period of pre-trial detention from 24 hours to 7 days with possible extension to 60 days upon order of the Office of the Public Prosecutor. Thus, the extraordinary powers of state security officials in the past were brought into the folds of ordinary police powers as of 2011. While members of the police force were accountable for their actions while on duty and complaints against them could be investigated and lead to criminal convictions, previous laws ${ }^{11}$ granted state officials of the intelligence agencies and security forces immunity from prosecution for abuse of power and criminal conduct while on duty except if accusations were filed by their immediate superiors. Not only were security and intelligence personnel not subject to judicial oversight by the ordinary courts, but it soon became apparent that they made decisions about arrests, prolonged

${ }^{11}$ Legislative Decree No. 14 of 15 January 1969 and Legislative Decree No. 64 of 2008. For more on these decrees, consult Syrian Center for Political and Strategic Studies (SCPSS) and Syrian Expert House 2013, 128, 159. 
detainment, accusations filed against detainees, referrals to the courts, investigations into suspicious deaths, etc. Their interference in the justice system and their appropriation of judicial functions normally exercised by prosecutors and investigating judges resulted in an increasing disempowerment of the judiciary, and this in many ways.

\subsection{Arrests and detainments}

Intelligence and security personnel, and the Syrian Arab army carry out the majority of arrests, and detainees are often held in non-official detention centers. A list of the main detention centers, both official and unofficial, compiled from testimonies of former detainees by the Independent International Commission of Inquiry on the Syrian Arab Republic established by the UN Human Rights Council ${ }^{12}$ shows that the greater number of these centers are controlled by the four major intelligence agencies of the regime: the Military Intelligence, the Air Force Intelligence, the Political Security Directorate and the General Security Directorate (UN Human Rights Council 2014, Annex V, 46-49). The Syrian regime has persistently denied the existence of such facilities, for example in its latest response (6 September 2011) to the concluding observations of the Committee Against Torture of the United Nations regarding the initial State report submitted by Syria (Syrian Arab Republic 2011, para. 49, p. 8). Attorney generals of the main courthouses in Syria are responsible for the periodic monitoring and inspection of state prison facilities, but do not have the authority to monitor the detention facilities of the intelligence agencies and the security forces.

According to the Criminal Code of Procedure, requests to prolong pre-trial detention periods must be approved by chief prosecutors. In an online news report, a prosecutor who worked for two years in the Rural Damascus district (rif dimashq) recounts how he witnessed the attorney general of the main courthouse blindly signing a pile of papers, which were requests for prolonged detainment, brought in by an officer of one of the many security branches. The attorney did not question the validity of the requests out of fear for his own safety. This was a routine event, and these official requests only represented a small number of cases of the people detained and were periodically presented to human rights commissions, delegates of the United Nations or the Arab League, that wanted to ascertain that detentions were not arbitrary but controlled by judicial oversight. This couldn't be farther from the truth as stated by the prosecutor (Ali 2014).

\subsection{Accusations and referrals to the courts}

As reported by numerous sources, the intelligence agencies and security forces basically decide the fate of detainees (International Bar Association's Human Rights Institute IBAHRI - 2011, 29-31; Violations Documentation Center in Syria - VDC - 2015, 5-6). The detainees can be released, or referred to military courts, even if they are civilians, to ordinary criminal courts - which is the better option since they will benefit from due

\footnotetext{
12 The IICI on the Syrian Arab Republic was established on 22 August 2011 and given the mandate to "investigate all alleged violations of International human rights law since March 2011 in Syria". All reports and press statements of the IICI on the Syrian Arab Republic can be consulted at the link provided; see Independent International Commission of Inquiry on the Syrian Arab Republic 2021-2011.
} 
process and be detained in regular government prison facilities where conditions are improved and they can receive visits (and often food) from their families -, or they can be referred to courts of exception, the Supreme State Security Court before its abolition in April 2011, the Counterterrorism Court since 2012, or the field courts, which are military courts of exception: the Military Field Court of Damascus is located in the Qaboun neighborhood (Amnesty International 2017, 6). Given the mass arrests in the first months of the March Revolution of 2011, many people were released. Statistics of the actual number of detainees are not reported by the government, but various human rights organisations and defense lawyers have provided estimations. Anwar al-Bunni, a well-known Syrian human rights lawyer now exiled in Berlin, provided estimates of arrests and referrals for the period of 2011-June 2015 (Al-Bunni 2018). Informed by inside sources and based on his estimates, al-Bunni claimed that more than 300,000 persons were arrested, half of whom were referred to military courts, military field courts and the Counterterrorism Court. In addition, 100,000 arrest warrants were issued for people who fled the country. The case files of more than 100,000 people were referred to the Counterterrorism Court, 50,000 of whom were sentenced in absentia. 30,000 people were detained in Adhra, the main prison of Damascus, the Saydnaya Military Prison on the outskirts of Damascus and the prisons of Homs, Hama, Lattakia, al-Suweyda, Tartus and Aleppo. 20,000 were released by investigating judges for lack of evidence regarding charges, in prison exchanges with opposition groups and because of presidential pardons.

The unprecedented amount of prosecutions and convictions strained resources of the Ministry of Justice, and new courts had to be opened and personnel appointed to administer them. The number of public prosecutors doubled in certain courthouses of Syria. For example, prior to 2011, the number of prosecutors assigned to the main courthouse in Damascus was around 25, but in October 2012, their number was increased to 42, 16 of whom were women (Decision No. 2442L of 30 October 2012). In June 2018, a total of 57 prosecutors (20 women) held office at the Damascus courthouse (Decision No. 2497L of 10 June 2018). In an unprecedented move in 2015, the High Judicial Council appointed "an army" of 259 prosecutors throughout Syria. All graduates of the seventh cohort of the Institute of Judicial Studies (renamed Higher Institute of Judicial Studies in 2013) were appointed as prosecutors (except for one) usually there are more judges than prosecutors appointed from each cohort. 64 were assigned to Damascus and its rural district, and the surprisingly large number of 54 were appointed to Tartus (Decision No. 3891L of 26 July 2015). In 2009, the total number of judges and prosecutors of this governorate was 58. Since the Revolution of 2011, the judicial personnel of Tartus has increased by two-fold. Is this because Tartus is one of the strongholds of the Syrian regime (and the site of Russia's naval facility in the Mediterranean), thus making it imperative that public order be maintained at all costs?

The number of investigating judges at the Damascus courthouse increased from 8 in 2010 to 10 in 2011 (Decision No. 2195L of 7 August 2011), and 11 in 2017 (Decision No. 3681L of 20 April 2017); and the number of Indictment Divisions that oversee their decisions increased from 3 in 2010 to 4 in 2012 (Decision No. 2442L of 30 October 2012). Similar additions were made to the courts and personnel of the Rural Damascus district: a third Assize Court was created in 2012 at al-Zablatani courthouse in Damascus (Decision No. 1332L of 20 May 2012). The number of prosecutors, investigating judges and criminal 
courts (first instance and appeal) were increased in areas where fighting intensified between opposition groups and regime forces: Daraya, Babbila (a southern suburb of Damascus), Duma (a suburb to the northeast of Damascus), al-Zabadani and al-Nabak, respectively 50 and $81 \mathrm{~km}$ north of Damascus. ${ }^{13}$ Likewise, more personnel and courts were added to the criminal jurisdiction of the Aleppo governorate after the city was occupied by opposition forces in 2012 up until December 2016 when the regime regained control of the city. Figures show that in 2010, there were 14 investigating judges, 6 Indictment Divisions, 8 first-instance criminal courts, 5 criminal appeal courts and 3 Assize courts (Decision No. 57L of 6 January 2010). These numbers rose in 2012 to 18 investigating judges, 8 Indictment Divisions, 10 first-instance criminal courts, 7 criminal appeal courts and 4 Assize courts (Hejar 2012). In recent years (2018-2020), the numbers have jumped again: 22 investigating judges, 9 Indictment Divisions, 11 first-instance criminal courts, 8 criminal appeal courts and 6 Assize courts (Correspondents 2018, Decision No. 1134/L of 5 May 2020).

Because of the overwhelming number of detainees referred to the Counterterrorism Court (CTC), additional personnel were assigned to the court. In September 2012, the CTC had one chamber with a panel of three judges, one of whom was a military judge. Three substitute judges were also appointed to the court in addition to four prosecutors and two investigating judges. And a chamber was established in the Court of Cassation to review decisions of the CTC with a panel of four judges (three regular judges and one substitute; Decree No. 317 of 29 August 2012). This was a small number of judicial officers to oversee the prosecution and trial of close to 35,000 people referred to the court by June 2013 according to the estimation of one Syrian lawyer who represented clients before the court. ${ }^{14}$ In order to process the growing number of cases referred to the CTC, investigating judges were increased to 5 , then to 7 in 2013; by 2015, their number had grown to 10 ( 3 of whom were military investigating judges; see Al-Bunni 2018). In 2015, there were 8 prosecutors working for the court (VDC 2015, 11), and a second chamber was added to the CTC (Zaman al-Wasl 2015). Postings on the Facebook page of the Ministry of Justice indicated that a third chamber of the CTC was formed (10 April 2019; Decree No. 117 of 3 April 2019), and that there were 11 investigating judges working for the court (25 February 2020; Decree No. 69 of 20 February 2020).

\subsection{The Counterterrorism Court (CTC)}

The judges and prosecutors of the CTC are endowed with unchecked decision-making power. The Counterterrorism Court Law No. 22 of 26 July 2012 states explicitly that the court does not abide by ordinary criminal procedure (Article 7). As a result, the requirements of due process and the rights of defendants to a fair and open trial, legal representation and recourse are systematically violated, as reported by international and Syrian human rights organisations, and Syrian lawyers who have represented defendants before the new court. In fact, what constitutes a terrorist act is so vaguely defined ${ }^{15}$ that the law has enabled state officials to detain and prosecute tens of

\footnotetext{
${ }^{13}$ Decision No. 2194L of 7 August 2011; Decision No. 1332L of 20 May 2012; Decision No. 358 of 21 December 2017.

${ }^{14}$ Another estimate was 50,000. See Human Rights Watch 2013.

${ }^{15}$ Human Rights Watch 2013 provides the following translation of Article 1 of the Counterterrorism Law No. 19 of 2 July 2012 which defines the act of terrorism as follows: "Every act that aims at creating a state of
} 
thousands of people who publicly expressed their opposition to the regime, in the streets and online, and peacefully demonstrated for social, economic and political reforms before the country became engulfed in an armed conflict. And those individuals who later documented the conflict and provided assistance and medical help to the victims were also prosecuted as terrorists. The Counterterrorism Court is rightly perceived as a tool of political repression. The appointment of an increasing number of ordinary judges and prosecutors to this court of exceptional jurisdiction - more than 90 individuals according to online sources consulted - has irredeemably tarnished the reputation and legitimacy of the entire justice system of Syria.

Though women were not originally appointed to the CTC which started working in September 2012, three were appointed a year later as investigating judges (Bara' 2013). According to information leaked by a source at the Ministry of Justice, some of the judicial officers appointed in 2012 were criticised by the National Security Bureau for not being severe enough in their decisions and having released too many detainees; these judges were summoned by the Bureau for questioning (All4Syria 2013, Bara' 2013). It was assumed by the High Judicial Council that because women judges were more obedient "by nature", the CTC would better comply with the executive orders to convict as many people as possible. These appointments were somewhat surprising given the fact that women were rarely appointed as investigating judges in Syria (Cardinal 2017, 250-251). In the past, women had not proven to be very effective in interviewing defendants, particularly men, who were repetitive offenders, accused of crimes of theft, murder, and sexual offenses. Of course, the majority of people who were detained under the Counterterrorism Law were ordinary citizens and not hardened criminals, so most probably, these women would not encounter the same intimidation and harassment when carrying out an investigation. Basima al-Mahdi and Fadiya Haj Hussein remained in office for a year, and then were transferred to courthouses in the Rural Damascus district. Of the ten women appointed to the CTC up until October 2017,16 it is the third appointee, Khulud al-Hamwi, who remained the longest serving officer of the court. She acquired the reputation of being very severe in her treatment of defendants, rarely dismissing charges against them (Al-Shami 2014). As reported by online sources, alHamwi, a Shiite originally from Foua, a government-held village in the governorate of Idlib under opposition control, was accused of being sectarian in her decisions because she consistently brought the most serious charges against Sunni defendants. Some reports claimed that her accusations against a group of rebels from Hama who were found guilty by the CTC and sentenced to hang for their crimes as terrorists by the president of the court, Rida Musa, also a Shiite, caused a major riot in the central prison

panic among the people, destabilizing public security and damaging the basic infrastructure of the country by using weapons, ammunition, explosives, flammable materials, toxic products, epidemiological or bacteriological factors or any method fulfilling the same purposes".

${ }^{16}$ According to another source, Basima al-Mahdi replaced Abla al-Ghuthani previously appointed as the third investigating judge of the CTC (VDC 2015, 11). Rima Ahmad Yunis, daughter of the former Minister of Justice, Ahmad Yunis, who was replaced shortly after the March Revolution, was appointed as a prosecutor to the CTC in September 2016: Decree No. 290 of 18 September 2016 (Syria Now 2016 and Syrian Days 2016). Rima al-Rifa'i was appointed as a prosecutor, and Wisam Yazbik and Suriyal Makarim as investigating judges along with Zahira Bashmani in October 2017. Article 6 of Decree No. 287 of 3 October 2017 stated that Lama Mayyus finished her mandate as a member of the Counterterrorism Court; the office she occupied was not specified (Ahmad 2017). 
of Hama (Al-Ulwani 2015). Even pro-regime lawyers and judges were critical of alHamwi's inhumane treatment of defendants, and stated that her conduct would simply increase anti-regime sentiments and even provoke possible acts of revenge (Al-Shami 2014). In fact, the former investigating judge of the CTC, Basima al-Mahdi, was targeted when her father was kidnapped, though the identity of his kidnappers and the motives for their actions remained unknown (All4Syria 2015).

Women's judicial functions in the CTC culminated with the nomination of Zahira Bashmani as president to the First Chamber of the CTC in 2017. ${ }^{17}$ Prior to this appointment, Bashmani had many years of experience as a criminal court judge and was the president of the Second Assize Court at the Damascus courthouse. Legal professionals such as the Syrian human rights lawyer Michel Shammas interpreted this nomination as a sign that court decisions would be of a harsher nature since Judge Bashmani is known for her staunch support of the regime (Shammas 2017). The only other woman to have presided over an exceptional court is Salwa Kadib when she was appointed president of the Economics Security State Court in the 1999. Before this appointment, she was the first and only woman in the Arab world to have served as president of an Assize Court in 1997, prior to her appointment to the Economics Security Court (Tishreen News 2012). ${ }^{18}$ She ended her career as the president of the Second Criminal Division of the Court of Cassation. In fact, Kadib came out of retirement to be appointed as the chief of the Judicial Inspections Department in 2017, a true demonstration of her loyalty to the regime. Single and without children, Bashmani and Kadib have devoted their lives to their careers and have risen to key positions in the criminal justice system undoubtedly because of their competence but also because of their steadfast support of the regime.

\section{Off-bench resistance in the public sphere}

Trochev and Ellett $(2014,69)$ explain that judges resort to off-bench resistance when their autonomy as judicial decision-makers is threatened by a "blatant interference in the judicial process". As described in section 4 of this article, Syrian prosecutors and judges were often coerced by the security forces - and continue to be - into taking decisions that violated the law. Through new legislation, state security officials even appropriated the judicial functions normally exercised by prosecutors and investigating judges. In addition, civilians were referred to exceptional courts and often condemned to severe punishments or even executed without due process. It was to be expected that members of the judiciary in Syria would eventually protest against such grave violations of human rights.

Based on their research and knowledge of post communist and sub-Saharan African countries, in addition to the "scholarly analysis and the media coverage of judicial politics in hybrid regimes"19- though in the case of Syria, the regime is authoritarian -

\footnotetext{
${ }^{17}$ Decree No. 287 of 3 October 2017. According to Decree No. 69 of 20 February 2020, Bashmani was still in office as President of the First Chamber of the CTC. The names of three other women judicial officers appeared in the decree: Fatin Siruwan, Rahaf Fahdah and Miriyam al-Daghli, which brings the total number of women appointed to the CTC to 13.

${ }^{18}$ This interview with Salwa Kadib was conducted in Damascus on 27 June 2006.

19 "Hybrid regimes" are described as "regimes combining democratic and authoritarian elements" (Trochev and Ellett 2014, 68).
} 
Trochev and Ellett propose a taxonomy of five strategies of off-bench resistance used by judges to preserve their autonomy as decision-makers: they 1 . engage in secret negotiations with the attacker; 2 . make secret alliances at home and abroad; 3 . go public; 4. engage in collective protest and 5. publicly mobilise allies at home and abroad (Trochev and Ellett 2014, 72-80). Since the March Revolution of 2011, state officials are constantly pressured by the security forces to comply with the regime's politics of repression. There is little room for negotiation, and in the cases to be discussed, many members of the judiciary were obliged to leave the country for fear of reprisals. As the following pages will show, initially members of the judiciary attempted to secretly consolidate their forces and form a network of support in order to protect their interests and enter into negotiations with the government for reforms. In light of the continued repression, judges and prosecutors then went public with their denunciations of the regime's systematic cover-ups of torture, killings and massacres. Many also publicly resigned from office and organised themselves into independent associations. Other judges and prosecutors joined the ranks of the Syrian opposition and campaigned abroad for regime change. It should be noted that the larger portion of off-bench resistance occurred in the north of Syria, in areas no longer under the control of the State, and eventually spilled over into Turkey. More surprisingly, members of the judiciary also mobilised inside the country, staging a courthouse protest in support of a colleague in Damascus. This last example of off-bench resistance is perhaps a sign that loyalties are shifting, and that the judicial branch of government can only sustain so much interference before the system implodes.

\subsection{The Judges' Club of Aleppo}

On 4 July 2012, 145 judges and public prosecutors throughout Syria came together to form an association, nadi quḍat sūrìy $\bar{a}$, the Judges' Club of Syria, in order to petition for reform to the judicial system. A majority of these activists, 125, were from Aleppo, and 42 of them met at the Bar Association in the city to adopt the founding statutes of the new association and elect members to the provisional board. 11 candidates ran and 7 were elected, among them, one women judge, Muna Shaykh Muhammad (Said 2012, The Legal Agenda 2012). The judges and prosecutors who founded the Judges' Club of Syria were not defectors; they had not left judicial office in protest of the regime's brutal repression of the popular uprising of March 2011 which continued to grow in momentum. They courageously assembled and demanded reforms, thus challenging the executive's tight control of the judiciary.

The creation of the Judges' Club of Syria in July 2012 was a form of off-bench resistance. It was a deliberate act of protest against the Syrian regime's instrumentalisation of the judiciary to quash the revolution. On 2 July 2012, two days before the founding of the Judges' Club, the Counterterrorism Law No. 19 was enacted, and the corresponding court structure to implement the law, the Counterterrorism Court was created on 26 July 2012. The counterterrorism measures put in place by the regime in July 2012 were a further violation of people's basic rights. Unfortunately, the Judge's Club of Syria did not succeed in uniting members of the judiciary to demand reforms in order to secure the independence and neutrality of the justice system. 


\subsection{Investigations into suspicious deaths and public denunciation of the perpetrators}

It is the duty of the Public Prosecution Office to investigate suspicious deaths. Since March 2011, a number of commissions were formed to investigate mass killings, massacres, assassinations and the discovery of mass graves. There is abundant proof that the intelligence agencies and security forces interfered in the official investigations of these commissions and dictated to public prosecutors the results to be published in their final reports. At the beginning of the Revolution, when state officials and members of the army wanted to fuel the opposition to the regime, they would publish videos of their defection from the State. On 30 August 2011, a video was published on YouTube that showed the attorney general of the main courthouse of Hama announcing his resignation and describing crimes against Syrians committed by the security forces. It is still unclear whether he was kidnapped by a group of rebels - this was the version of events disseminated by state media outlets - or he defected on his own accord. In his video statement (BBC News 2011), Adnan Bakkour referred to "the arbitrary arrests of peaceful protesters" with close to 10,000 people detained, "the killing of 72 prisoners in Hama's central prison on 31 July 2011," the torture of prisoners detained by the security forces and the death of approximately 320 under torture, in addition to "the burying of more than 420 victims in mass graves in public parks by the security forces" and proregime militias; he was obliged to report that these victims had been killed by rebel groups and not by regime forces as was the case. Eventually, in 2012, prosecutors and judges started resigning from office in self-published videos in order to denounce the abuses of the regime and the interference of its security forces in the administration of justice. The first video was published on 25 July 2012 by Talal Hushan, a prosecutor assigned to the village of Mahardah, ${ }^{20}$ north of Hama. Hushan had been appointed by the government to head a commission that was to investigate a massacre that took place on 6 June 2012 in al-Qubeir, a village $20 \mathrm{~km}$ west of Mahardah (Al-Qubeir Massacre 2021). The commission concluded that the massacre had been carried out by "armed terrorists". In his defection video which can be viewed on YouTube with English subtitles, ${ }^{21}$ Hushan clearly stated that al-Qubeir massacre was committed by the Syrian army and the regime's militia. His statement contradicted the conclusions of the commission he headed which exonerated the regime's forces. In the video, he pleaded with his colleagues to resign from office so that history would not remember the judicial corps as having collaborated with the regime to oppress the Syrian people. Soon after, Hushan established with fellow defectors an independent association of judges and prosecutors on 9 September 2012 called Majlis al-qad̄a $\bar{a}^{\prime}$ al-sūrì al-ḥurr, ${ }^{22}$ the Free Syrian Judicial Council, which opposed the regime, investigated crimes against humanity and war crimes committed by officials, and eventually came to work in coordination with the National Coalition for Syrian Revolutionary and Opposition Forces formed in November 2012 and recognised as "the sole legitimate representative of the Syrian people" by more than twenty states in Europe, the Arab World, and North America at the time.

\footnotetext{
20 "Mhardeh" is an alternative spelling.

${ }^{21}$ A complete version of the video in Arabic is available from Ugarit News - Syria 2012a. A partial English translation of the video is available from Syrian Scenes 2012.

${ }^{22}$ A video of Talal Hushan announcing the creation of the Free Syrian Judicial Council was posted on YouTube; see Mglis kudat 2012.
} 
Judges were also prevented from initiating investigations into suspicious deaths. Iman Shahud, an appeal court judge at the main courthouse of Idlib, north of Hama, was obliged to flee Syria with her family after being threatened by security forces. In an interview (Martini 2014), Shahud explained that she wanted to open an investigation into her brother's death. He was arrested by security forces during a peaceful demonstration at the beginning of the Revolution, and because of severe beatings while in custody, landed in the hospital. He was apparently assassinated in the National Hospital of Idlib. Because of her request for an investigation, she became a target of the regime. She refused to appear to a summons issued by the security forces. Shortly afterwards, her house was illegally searched. Other family members, this time minors, were detained, but the judge did not even attempt to pursue the issue. Eventually, Shahud had to attend a hearing before the High Judicial Council and was sanctioned for misconduct based on reports filed by the security forces. She finally decided to leave Syria with her husband and children for fear of being arrested. They took refuge in Turkey. The threat of being detained and eventually killed was a real possibility.

Shahud acted as the vice-president of another judicial association established on 8 February 2013, Majlis al-qadā' al-mustaqil, the Independent Judicial Council, presided over by Amir Bitar, a former judge of the Indictment Division of the Idlib courthouse who resigned from office with eight other prosecutors and judges from Idlib on 9 December 2012. ${ }^{23}$ While in Turkey, Shahud helped found an organisation for the defense of human rights, the Association for the Defense of the Rights of the Victims of the Syrian Revolution, and was elected as its president in February 2014. However, shortly after, she immigrated to Europe with her family in order to start a new life.

\subsection{Judges and Prosecutors form associations and join the Syrian Opposition}

There are about 100 judges and prosecutors who publicly announced their opposition to the regime and left the ranks of the judiciary. Among them are five women: Iman Shahud, as previously mentioned, and one of her colleagues from Idlib, Sumaya Ariyan, who left Syria and immigrated to one of the Golf countries. Rasha Rajab, a young prosecutor from the Rural Damascus district, is the only woman, to the author's knowledge, to have posted a video of herself announcing her resignation and opposition to the regime. ${ }^{24}$ She ended the short video with the popular rallying cry of the Syrian uprising: "Long Live Syria, Free and Proud" ('äshat surīya hurra abìya). Bayda al-Hamud, originally from al-Raqqa, took refuge in Turkey when the Islamic State took over her city. She was elected as a member of the board of directors of the Syrian Judicial Council (majlis al-qad̄a al-sūrì) in Gaziantep, Turkey (Majlis al-qaḍā'al-sūrī 2016). Hanadi Abou Arab, a judge from Damascus, became the vice-president of the Syrian Negotiation Commission (SNC) - formerly known as the High Negotiations Committee (HNC) of the Syrian Opposition - which was established in December 2015 to participate in the UN-led peace talks in Geneva. In 2019, she was appointed to the Syrian Constitutional Committee, formed under the auspices of the United Nations in Geneva, which had the mandate to revise the 2012 Constitution with the aim of resolving the armed conflict

${ }^{23}$ The video of this group resignation is available from Ugarit News - Syria 2012b.

${ }^{24}$ In October 2013. The video is no longer available. 
through a peaceful political process. This "Syrian-led, Syrian-owned" committee ${ }^{25}$ is composed of 150 members and divided equally into three groups: the Government, the Opposition and Civil Society. Iman Shahud also became a member, but of the Civil Society group which comprised individuals (pro-regime, oppositional, neutral) who were selected by the UN and vetted by the Syrian government and the Syrian Negotiation Commission. She was also chosen to sit on the drafting committee made up of 45 members ( 15 from each group), most probably because of her 25 years of experience as a lawyer and judge. Another noteworthy appointment to the drafting committee, a delegate of the Syrian Government, is Jamila al-Sharbaji (Shaar and Dasouki 2021), professor of constitutional law and member of the Supreme Constitutional Court as previously mentioned.

These are some of the stories of women judges and prosecutors who publicly resigned from office to voice their opposition to the Syrian regime and its politics of repression. However, an important story surfaced online which illustrates that off-bench resistance is also practiced by members of the judiciary who have remained in office in Syria.

\subsection{A woman judge defies a member of Parliament and the Minister of Justice, and becomes a victim of family connections and political power}

Judges and prosecutors in Syria are subjected to the interference of the intelligence and security personnel in judicial matters in addition to living under the constant threat of disciplinary actions when they do not comply with the regime's policies and practices. Members of the judiciary, particularly lower-ranking members, are also subject to internal pressures and intrigues that involve higher-ranking judges and prosecutors, and their networks of political influence and power. Such is the case of a story widely shared on Arab social media and online news outlets of how political power and rank can be used by one member of the judiciary to crush another. At the pinnacle of power is the former Minister of Justice, Najm Hamad al-Ahmad, who served between August 2012 and March 2017. He was also member of the Regional Command of the Ba'th Party and former law professor and head of the Public Law section at Damascus University. His victim, the lowest possible ranking member of the judiciary, a newly appointed civil peace court judge, Sidra Hanafi, who had recently graduated from the Institute of Judicial Studies in the top 15\% of her class (Decision No. 3891L of 26 July 2015). Hanafi had just embarked on her dream career when men of power decided to put an end to it, or so they thought.

On 10 May 2016, Judge Sidra Hanafi conducted an on-site visit with her team of experts: a real estate expert, a man, her female court clerk, and the lawyer of the plaintiff who was a woman. In all, the judicial commission was composed of one man and three women. Judge Hanafi was to decide on a claim filed by the owner of an apartment against a tenant who had not paid the rent and refused to vacate the premises. The apartment was located in the newly developed and rather posh suburb of Damascus, Mashru' Dummar. Unfortunately for the judge, the tenant, Jihad al-Shakhir, was a member of Parliament and the maternal first cousin of the Minister of Justice.

\footnotetext{
25 The rules of procedure of the Syrian Constitutional Committee are contained in the official document of the Security Council S/2019/775 (UN Security Council 2019).
} 
Jihad al-Shakhir refused to let the judge and her team enter the apartment. He informed them that he was a member of Parliament, close to the regime, and had an army of militiamen at his command ${ }^{26}$ - this last piece of information was an indirect threat. The judge replied that she would be obliged to decide in favor of the plaintiff since she had been denied access to the apartment. At that point, al-Shakhir lost control, took out his gun and threatened the judge with it. His son and bodyguards grabbed the members of the commission, forced them into the apartment and held them hostage. For a couple of hours, the judge and her team were verbally threatened and physically assaulted. The judge was bleeding and eventually lost consciousness. During the ordeal, members of the team said that al-Shakhir called his cousin, aka the Minister of Justice, claiming that he had caught the judge stealing gold and money during the on-site visit and had detained her. In the meantime, members of the committee were able to call the attorney general of the Damascus courthouse informing him of what had happened to Judge Hanafi and themselves, and how they were being held against their will and physically assaulted. But help did not come right away. After negotiations with al-Shakir, ${ }^{27}$ Judge Hanafi was finally released and taken to the hospital. In the medical report, it was said that Judge Hanafi suffered a concussion and minor injuries (wounds and bruises). Members of the commission also suffered injuries: the real estate expert was said to have a broken jaw and teeth (Fadil 2016). Upon order of the chief attorney general at the Damascus courthouse, al-Shakhir and his son were questioned by Mashru' Dummar's local police chief, but somehow the investigation was dropped after the Speaker of Parliament and the Minister of Justice intervened. In the meantime Judge Hanafi's lawyer filed a criminal complaint against al-Shakhir demanding for his arrest, despite the fact that as a member of parliament, al-Shakhir benefited from parliamentary immunity.

But nothing was done to further the investigation. At that point, judges and prosecutors at the Damascus courthouse became vocal. On their Facebook accounts, they expressed their solidarity with Judge Hanafi, and were indignant for the lack of respect shown to a judge by a member of Parliament, who had been elected under the supervision of the judiciary. They pressured the chief attorney general to continue the investigation, and both Jihad al-Shakhir and his son were detained and questioned by the sixth investigating judge at the Damascus courthouse. The son was held for further examination, but the father was released. This ignited the anger of the judges and prosecutors at the Damascus courthouse, and they decided to suspend their proceedings on Sunday 15 May 2016. Under the mounting pressure, the investigating judge reopened the case.

These events were reported by an online newspaper and news website known for their opposition to the Syrian regime, Zaman al-Wasl and All4Syria. ${ }^{28}$ Judge Hanafi also gave her account of the incident in a letter of appeal for justice, addressed to the president of the Syrian Arabic Republic, "Doctor Bashar Hafiz al-Asad". A copy of this letter was

\footnotetext{
${ }^{26}$ Consult Awad and Favier 2020, 21-22 to learn more about members of parliament involved in militia activities in support of the regime.

${ }^{27}$ According to Judge Hanafi's version of events, it was the security forces that rescued her and the members of the judicial commission (Al-Tawil 2017a; see also Fadil 2016).

${ }^{28}$ Abd al-Haqq 2016 and Al-Tawil 2017a. A comment posted at the end of the Zaman al-Wasl article states that al-Shakhir is not the maternal cousin of Minister al-Ahmad.
} 
leaked to the media by an unknown source at the Ministry of Justice. It was first published online by the pro-regime website Sahibat al-jalala (Majesty News.com) on 9 January 2017 (Halftruthsy 2017). All4Syria picked it up and republished it on 15 January 2017 (Al-Tawil 2017a).

Judge Hanafi wrote the letter after she received a formal summons to appear before the High Judicial Council for misconduct due to a complaint lodged by Jihad al-Shakhir accusing her of having committed a crime. In her letter to the President, she, in turn, accused the Minister of Justice, Najm al-Ahmad, the head of the Judicial Inspections Department, Dib Muqtran, and the judicial inspector, Radwan al-Hujja, of perverting the course of justice, and denying her the right to defend herself. Here then is the end of the story as told by Judge Hanafi.

Shortly after al-Shakhir was detained for questioning, his family proposed to compensate Judge Hanafi if she retracted her complaint against him. They offered her a compensation of tens of millions of Syrian pounds. She did not want to withdraw her complaint and accept compensation. The Minister of Justice intervened and strongly suggested she accept the compensation to avoid any form of reprisal on the part of Jihad al-Shakhir, but mentioned a lesser amount than initially proposed. He also threatened to transfer her to the governorate of Deir Ezzor, a highly insecure region of Syria partially under the control of the Islamic State. A year earlier in July 2015, the Syrian Arab News Agency, SANA, reported that a woman judge assigned to Tadmur had been executed by the Islamic State for not cooperating with them (SANA 2015).

Minister of Justice al-Ahmad convened a meeting in his office with Judge Hanafi and members of the judiciary involved in the case. He informed them that an agreement had been made for compensation for the amount of six and a half million Syrian pounds. Consequently, all criminal proceedings were suspended, and Jihad al-Shakhir and his son were released from custody. However, that was not the end of the story.

The Minister of Justice decided to take revenge on Judge Hanafi for having exposed the criminal behaviour of his cousin. She was transferred to the Rural Damascus district, and her husband, Tamam Da'ud, also a judge at the Damascus courthouse, was unofficially relieved of his duties. When Hanafi confronted the Minister of Justice, he asked her to resign or he would remove her from office. The other option was that she could reconcile with his cousin, change her version of events and return part of the compensation money.

When she attended the first hearing before the High Judicial Council, Judge Hanafi learned that she was accused of blackmailing al-Shakhir into paying her a sum of money. She was asked to respond to the accusation in a written statement, which she did, explaining that the amount paid to her was a form of compensation they had agreed upon. She was then accused of having received the compensation in American dollars rather than in Syrian pounds. It is against the law in Syria to receive a payment in a foreign currency (Legislative Decree No. 54 of 4 August 2013). Anyone who violates the law regarding a sum of money equal to or more than a million Syrian pounds or 5 thousand US dollars can be imprisoned for 3 to 10 years with hard labour and be subject to pay a fine worth the amount of money exchanged (Article $2 \S 2$ ). The young judge stated that she was subsequently denied the right to defend herself. Regarding the second accusation, she declared herself innocent. 
In the last part of her letter, Judge Hanafi appealed to the President to come to her defense: "In my country, the one that you lead, it is impossible that the perpetrator of a crime can be acquitted and the victim convicted. Mr. President, you have the authority to initiate a full investigation in order to arrive at the truth" (Al-Tawil 2017a). Why appeal to the President of Syria? Because, as stated in the Judicial Authority Law, the President of the Republic presides over the High Judicial Council, and is therefore the only member of the executive to have authority over the Minister of Justice who acts as his deputy (Judicial Authority Law No. 98 of 15 November 1961 with amendments, Article 65). Finally, Judge Hanafi requested that her case be heard by the plenary session of the Court of Cassation. ${ }^{29}$ In her opinion, it was the only way to secure a fair and impartial trial.

Three months after the publication of the letter, in March, the Minister of Justice Najm al-Ahmad was replaced, and it was later reported that he was arrested at the Damascus airport attempting to flee the country (Enab Baladi 2017, Al-Tawil 2017b). Sidra Hanafi continued to work as a prosecutor in the Rural Damascus district (Decision No. 4951L of 3 August 2017), and in October 2017, the High Judicial Council dismissed the complaint against her. ${ }^{30}$ As for Jihad al-Shakhir, he ceased to be a member of parliament in 2016 when new elections were held.

\section{Conclusion}

The regime of Bashar al-Asad deployed the strength of its military and security forces to crush the popular protests of 2011 and remain in power; it also used the law and the courts. The criminal justice system was systematically utilised as a tool by the regime to oppress and terrorise the population into submission. Never had such a large number of ordinary judges, prosecutors and investigating judges been appointed to a court of exception, the Counterterrorism Court, and applied a law, the Counterterrorism Law, that so blatantly violated the basic legal rights of all Syrians. In the past, it only took a handful of judges and prosecutors for the workings of the State Security Court in comparison to ten times more personnel needed for the functioning of the CTC. In addition, hundreds of more prosecutors, investigating judges and judges of the Indictment Division were appointed to the courthouses, and many more ordinary criminal courts at all levels were established throughout the country in order to expand the criminal justice system of the State and its capacity to prosecute and punish a people.

Previous research conducted by the author demonstrated that women members of the judiciary worked overwhelmingly in the criminal justice system: about $60 \%$ of women began their career as public prosecutors, $43 \%$ of them gained more experience as criminal court trial judges than civil court trial judges, and $30 \%$ of them had worked exclusively in the criminal justice system (Cardinal 2017, 244). Therefore, it is safe to assume that women members of the judiciary have contributed significantly to implementing the State's repressive criminal justice policy. In that respect, judicial officers, women like men, who work in the criminal justice system have gained an immense amount of judicial power, especially those appointed to the CTC since

\footnotetext{
${ }^{29}$ The procedure for this type of trial is detailed in Articles 114-116 of the Judicial Authority Law No. 98 of 1961 with amendments.

${ }^{30}$ As stated on a Facebook account devoted to judges and lawyers in Syria: Yahiamahmod123 2017.
} 
standard criminal procedure is not followed in this court and much more is left to the discretion of the judicial officer.

Nonetheless, the individual stories of judges and prosecutors highlighted in this article indicate across the board that, ultimately, members of the judiciary have been disempowered. All members of the judiciary, even those members appointed to the CTC, can be pressured by the security forces to modify their decisions, to convict rather than release a defendant despite the lack of evidence or the use of evidence obtained under torture. Judicial officers were threatened if they made enquiries into suspicious deaths or arbitrary arrests and detentions. Prosecutors were coerced into filing false reports about the cause of death of the detained and innocent civilians, about the identity of the perpetrators of a massacre; they were forced to rubberstamp decisions of prolonged detainment and indictments dictated by the security forces. These and many other accounts demonstrate that members of the judiciary did not and do not unanimously support the politics of repression of the Syrian regime.

The stories of Iman Shahud and Sidra Hanafi are distinct because they reveal the inner workings of the Ministry of Justice, of how the minister exploited his executive power as head of the High Judicial Council to reprimand judges who did not comply with the regime's politics of repression or who acted against his own personal interests and prerogatives or those of highly placed individuals connected to him, who financially and militarily support the regime. Shahud stated that she left office for two reasons: the threat to her life and her family, and her incapacity to carry out her duties to uphold the law and protect people... she did not want to the have "the blood of the Syrian people on her hands" (Martini 2014). Sidra Hanafi's ordeal is an extreme example of the difficulty women experience in exercising their authority as judicial officers. Interviews conducted by the author with women judges and prosecutors from 2004-2009 revealed that it was a typical experience that women conducting out-of-court visits did not always obtain full cooperation from individuals. Without a doubt, the fact that Judge Hanafi was accompanied by two other women and only one man added to her perceived weakness and vulnerability; she did not command authority first as a woman and second as a judge. In addition, the general lawlessness that Syrian society has descended into could explain why she was attacked with such impunity. Judge Hanafi's ordeal also revealed the general weakness of the judiciary. Despite the support she received from fellow judges and prosecutors at the Damascus courthouse who demanded that a proper criminal investigation be conducted, this collective effort to obtain justice for a colleague was ineffective. It is only when the minister was ousted, that Judge Hanafi was finally absolved from any charge of misconduct.

Why is it important to highlight stories of off-bench resistance? It is extremely important to do so because, at the end of the day, when the conflict will end and Syrians can start to rebuild their country, they will have to cooperate, no matter what their differences, political convictions and loyalties may be. A system of transitional justice will have to be put in place in order to address the systematic violation of human rights during the present conflict and the past decades of state repression and political violence. Syrian judges and prosecutors will have a role to play in establishing truth commissions, deciding on forms of reparation, prosecuting and judging crimes against humanity and war crimes - though the integrity of the judicial officers who served on the 
Counterterrorism Court is undeniably compromised and should result in their exclusion from the transitional justice process. Syrian legal experts will also have to work towards proposing a series of reforms to the justice system which will ensure the independence of the judiciary and restore confidence in the courts - the most important reforms being the abolition of courts of exception and the repeal of laws that violate basic human rights and freedoms and grant judicial powers to non-judicial state officials. Stories of resistance highlight the fact that many Syrian judges and prosecutors do believe in the idea of basic human rights and have struggled to defend those rights. These stories give hope that some individuals can be trusted with the mandate to defend the rights of citizens and ensure that state institutions will prevent a repetition of past abuses and atrocities.

\section{References}

'Ali, R., 2014. Mudhakkirāt qāḍin sūrī...kull hadhā kāna yaḥduth wa-akthar [Memoirs of a Syrian prosecutor... What really happened and even worse]. Orient News [online], 5 February. Availabe from: http://www.orientnews.net/ar/news show/7613 [Access 16 January 2021].

'Ali, R., 2018. Al-maḥkamat al-dustūrīya al-'ulyā fī sūrīya: al-wāqi' wa-l-ma'mūl [The Supreme Constitutional Court in Syria: between reality and hope]. The Arab Reform Initiative [online], 18 April. Available from:

http://syrianlegalforum.net/publications/view/46 [Access 25 January 2021].

Abd al-Haqq, I., 2016. 'Uḍw majlis al-sha'b wa-șāhib sawābiq wa-ibn khālat wazīr al'adl yuhāāwil qatl qāḍìya [Cousin of the Minister of Justice, a member of Parliament with a history, tries to kill a female judge]. Zaman al-Wasl [online], 14 May. Available from: https://www.zamanalwsl.net/news/article/70902/ [Access 21 June 2021].

Abdel Nour, A., 2020. Syria's 2020 parliamentary elections: the worst joke yet.Mei@75 [online], 24 July. Available from: https://www.mei.edu/publications/syrias-2020parliamentary-elections-worst-joke-yet [Access 19 January 2021].

Abu al-Zayn, A., 2010. Al-qanūn raqm (57) L [Law no. 57L], [Posting], 16 January. AlMarkaz al-sūrì l-il-istishārāt wa-l-dirāsāt al-qanūniyya [Syrian Center of Legal Consultations and Studies], al-bara-sy.com/forum/archive/index.php/t-8460.html [No longer online; Access 13 July 2016].

Abu al-Zayn, A., 2012. Al-marsūm 173 li-'ām 2012 tasmīyat ra'îs wa-'a'ḍā' al-maḥkama al-dustūrìya al-'ulyā [Decree no. 173 of 2012: designation of the president and members of the Supreme Constitutional Court]. Damascus Bar Association [online], 22 May. Available from: https://www.damascusbar.org/AlMuntada/showthread.php?t=22986 [Access 14 June 2021].

AFP, 2018. Syria war has killed more than 350,000 in 7 Years: monitor. Daily Mail [online], 12 March. Available from:

https://www.dailymail.co.uk/wires/afp/article-5490129/Syria-war-killed-350-0007-years-monitor.html [Access 15 January 2021]. 
Ahmad, S., 2017. Qāọīya tatawallā ri'āsat maḥkamat al-irhāb li-l-marra al-'ūlā fī sūrīyā [A woman judge presides over the Counterterrorism Court for the first time in Syria]. All4Syria [online], 4 October. Available from: https://web.archive.org/web/20171004232239/http://all4syria.info/Archive/446729 [Access 14 June 2021].

Al-Bunni, A., 2018. Irhāb al-mahākim fī sūrīyā [The terrorism of courts in Syria]. Syrian Center for Legal Studies and Researches [online], 11 October. Available from: https://sl-center.org/?p=373 [Access 16 January 2021].

All4Syria, 2012. Asmā' al-quḍāt al-mu'ayyinīn al-yawm ka-quḍāt maḥākim al-irhāb fī sūrīyā [The names of the judicial officers appointed today as members of the Counterterrorism Court in Syria]. All4Syria [online], 16 September. Available from:

https://web.archive.org/web/20120918055220/http://www.all4syria.info/Archive/5 $\underline{4249}$ [Access 14 June 2021].

All4Syria, 2013. Al-ajhiza al-amanīya taqif warā’ taghyīr quḍāt maḥkamat al-irhāb [Security Services are behind the dismissal of judges of the Counterterrorism Court]. All4Syria [online], 3 November. Available from:

https://web.archive.org/web/20131108123750/http://www.all4syria.info/Archive/1 $\underline{08905}$ [Access 14 June 2021].

All4Syria, 2015. Ikhtițāf wālid qāọīya bi-maḥkamat al-irhāb bi-dimashq [Kidnapping of the father of a former judge of the Counterterrorism Court in Damascus].

All4Syria [online], 2 January. Available from:

https://web.archive.org/web/20150726134943/http://www.all4syria.info/Archive/1 $\underline{86514}$ [Access 14 June 2021].

Al-Qubeir massacre, 2021. Wikipedia [online], 5 January. Available from: https://en.wikipedia.org/wiki/Al-Qubeir massacre [Access 26 January 2021].

Al-Shabbi, S., 2016. Bi-l-ṣūwar... al-i'lān 'an milād jam'īyat al-qāḍīyāt al-tūnsīyāt [News in photos: announcement of the birth of a Tunisian women judges association]. Assabah News [online], 25 November. Available from: http://www.assabahnews.tn/print/136935 [Access 25 January 2021].

Al-Shami, F., 2014. Irhāb al-qādịya khulūd al-ḥamwī [The terrorism of Judge Khulud al-Hamwi]. All4Syria [online], 24 April. Available from:

https://web.archive.org/web/20140426112037/http://www.all4syria.info/Archive/1 $\underline{43656}$ [Access 14 June 2021].

Al-Shantuf, A., 2018. Ta'sīs al-ittihāa al-'arabī l-il-quḍāt: țumūḥ fị khiḍamm al-ikrāhāt [The creation of the Arab Union of Judges... aspirations in an ocean of constraints]. The Legal Agenda [online], 23 September. Available from: http://www.legal-agenda.com/article.php?id=4852 [Access 25 January 2021].

Al-Tawil, M., 2017a. Qāḍīya tunāshid bashār al-asad li-inqādhiha min wazīr al-'adl: qarībuh ḍarabanī wa-ashtakā [A woman judge implores Bashar al-Asad to rescue her from the Minister of Justice: his relative beat me, then filed a complaint against me]. All4Syria [online], 15 January. Available from: 
https://web.archive.org/web/20170115115106/http://all4syria.info/Archive/379542 [Access 17 July 2017].

Al-Tawil, M., 2017b. Șulutāt al-nizāām tulqī al-qabḍ 'alā wazīr al-'adl al-ma'zūl [Regime authorities arrest ousted Minister of Justice]. All4Syria [online], 4 May. Available from:

https://web.archive.org/web/20170811053729/http://www.all4syria.info/Archive/4 $\underline{07545}$ [Access 14 June 2021].

Al-Ulwani, A., 2015. Aḥkām al-i'dām tash'al fatīl al-ghadab fī sijn ḥamā...wa-hadhihi khiyārāt al-nizām! [Death sentence lights a fuse of anger in Hama's main prison... that's one of the regime's options!"]. Orient News [online], 27 June. Available from: http://www.orient-news.net/ar/news show/88513 [Access 25 January 2021].

Amnesty International, 2017. Human slaughterhouse. Mass hangings and extermination at Saydnaya Prison, Syria [online], 7 February. London: Amnesty International. Available from: https://www.amnesty.org/en/documents/mde24/5415/2017/en/ [Access 25 January 2021].

Awad, Z., and Favier, A., 2020. Elections in Wartime: The Syrian People's Council (20162020) [online]. Florence: Robert Schuman Centre for Advanced Studies, European University Institute. Available from: https://doi.org/10.2870/365967 [Access 10 August 2021].

Bara', U., 2013. Tashkīlat maḥkamat al-irhāb al-jadīda bi-l-asmā' ... dawruha wa-țarīqat 'amaliha [New composition of the Counterterrorism Court: names of members... the role and the functioning of the court]. All4syria [online], 1 November.

Available from:

https://web.archive.org/web/20131108120201/http://all4syria.info/Archive/108466 [Access 14 June 2021].

BBC News, 2011. Syria: Hama legal chief denies resignation was forced. BBC News [online], 1 September. Available from: https://www.bbc.com/news/world-middleeast-14753051 [Access 20 January 2021].

Cardinal, M.C., 2017. The politics of exclusion: Women public prosecutors and criminal court judges in Syria (1975-2009). In: N. Sonneveld and M. Lindbekk, eds., Women Judges in the Muslim World: A Comparative Study of Discourse and Practice [online]. Leiden/Boston: Brill, 237-258. Available from: https://doi.org/10.1163/9789004342200_010 [Access 25 January 2021].

Correspondents, 2018. Taḥ̣̂̄ināt al-mu'tamar al-qaḍā'î̀ al-sādis al-ladhī sa-yanaqid ghadan fì halab ma'a murāsilinā al-zamīl fu'àd izmirlī [Preparations for the sixth Judicial conference held tomorrow in Aleppo with our correspondent Mr Fuad Izmirli] [Facebook post]. Murāsilūn [Correspondents] Syria [online], 5 December. Available from: https:/facebook.com/correspondents.syria/videos/2301370043208802 [Access 25 January 2021].

Damas Times, 2016. Al-lajna al-qadā'īya bi-țarțūs... nisbat al-mushāraka fī-l-intikhābāt tatajāwaz al-50\% [The judicial elections committee in Tartus... voter participation 
in the elections exceeds 50\%]. Damas Times [online], 14 April. Available from: http://www.damas-times.com/?page=8\&page id=15885 [Access 4 June 2021].

D-P News, 2014. Mashrū’ marsūm li-ziyādat rawātib al-quḍāt al-sūrīyīn 150 \% [Draft legislation to increase salaries of Syrian judges and prosecutors by $150 \%]$. D-P News [online], 24 April. Available from: https://web.archive.org/web/20140426134431/http://www.dpnews.com/pages/detail.aspx?articleid=162239 [Access 14 June 2021].

Enab Baladi, 2017. Ilqā' al-qabḍ ‘alā wazīr al-‘adl al-sābiq fī mațār dimashq [Arrest of the former Minister of Justice at the Damascus airport]. Enab Baladi [online], 4 May. Available from: https://www.enabbaladi.net/archives/147838\# [Access 15 January 2021].

Fadil, A., 2016. Barlamānī yaqful bābah 'alā qāọiya sūrīya wa-yushbi'uha ḍarban [A Syrian member of parliament locks up a judge and gives her a severe beating]. AlArabiya [online], 12 May. Available from: https://www.alarabiya.net/ar/arab-andworld/syria/2016/05/12/\%D8\%A8\%D8\%B1\%D9\%84\%D9\%85\%D8\%A7\%D9\%86\% D9\%8A-\%D9\%8A\%D9\%82\%D9\%81\%D9\%84\%D8\%A8\%D8\%A7\%D8\%A8\%D9\%87-\%D8\%B9\%D9\%84\%D9\%89\%D9\%82\%D8\%A7\%D8\%B6\%D9\%8A\%D8\%A9\%D8\%B3\%D9\%88\%D8\%B1\%D9\%8A\%D8\%A9\%D9\%88\%D9\%8A\%D8\%B4\%D8\%A8\%D8\%B9\%D9\%87\%D8\%A7\%D8\%B6\%D8\%B1\%D8\%A8\%D8\%A7\%D9\%8B- [Access 25 January 2021].

France 24 and AFP, 2019. En Algérie, plus de 1000 juges refusent de superviser la présidentielle. France 24 [online], 11 March. Available from: https://www.france24.com/fr/20190311-algerie-1000-juges-magistratspresidentielle-bouteflika-election-manifestations-avocats [Access 25 January 2021].

General Organisation of Radio and TV - Syria (ORTAS), 2011. Al-lajna al-'ulyā l-ilintikhābāt tushakkil al-lijān al-qaḍā'îya al-far'īya fī-l-dawā'ir al-intikhābīya bi-lmuhāfazāa [High Elections Committee forms judicial branch committees in the electoral districts of governorates]. ORTAS [online], 29 September. Available from: http://www.ortas.gov.sy/index.php?p=13\&id=79987 [Access 16 January 2021].

Ghamroun, S., 2016. À qui s'adressent les juges? Les magistrats tunisiens et égyptiens face aux aléas de la représentation professionnelle. In : E. Gobe, ed., Des justices en transition dans le monde arabe? Contributions à une réflexion sur les rapports entre justice et politique [online]. Rabat: Centre Jacques-Berque, 169-188. Available from: https://doi.org/10.4000/books.cjb.770 [Access 25 January 2021].

Ginsburg, T., and Moustafa, T., eds., 2008. Rule by law: The politics of courts in authoritarian regimes. Cambridge/New York: Cambridge University Press.

Halftruthsy, 2017. Naqlan 'an al-zamila șāhibat al-jalāla... hal al-qaḍā' al-sūrī bi-khayr? [Is the Syrian judiciary all right? (Source: Majesty News)] Facebook post. Halftruthsy [barnāmaj nifș al-haqīqa 'alā al-faḍa' '̀ya al-sūrīya] [online], 11 January. Available from: 
https://www.facebook.com/halftruthsy/photos/\%D9\%86\%D9\%82\%D9\%84\%D8\% A7-\%D8\%B9\%D9\%86-

\%D8\%A7\%D9\%84\%D8\%B2\%D9\%85\%D9\%8A\%D9\%84\%D8\%A9-

\%D8\%B5\%D8\%A7\%D8\%AD\%D8\%A8\%D8\%A9-

\%D8\%A7\%D9\%84\%D8\%AC\%D9\%84\%D8\%A7\%D9\%84\%D8\%A9-

\%D9\%87\%D9\%84-\%D8\%A7\%D9\%84\%D9\%82\%D8\%B6\%D8\%A7\%D8\%A1-

\%D8\%A7\%D9\%84\%D8\%B3\%D9\%88\%D8\%B1\%D9\%8A-

\%D8\%A8\%D8\%AE\%D9\%8A\%D8\%B1-\%D8\%AD\%D9\%86\%D9\%81\%D9\%8A-

\%D8\%AA \%D8\%AA \%D9\%87\%D9\%85-\%D9\%88\%D8\%B2\%D9\%8A\%D8\%B1-

\%D8\%A7\%D9\%84\%D8\%B9\%D8\%AF\%D9\%84-

\%D8\%A8\%D8\%A7\%D9\%84\%D8\%A7\%D9\%86\%D8\%AD\%D9\%8A/1881082555459 $\underline{858}$ [Access 21 June 2021].

Hamiju, M.M., 2016. Naqābat al-muhāmīn: mamnū' al-ḥakī 'alā al-qaḍā' ‘alā

"facebook" ... al-sakīf l-il-waṭan: taḥwīl muhāmīn ilā al-muhāsaba al-maslakīya linashāțihim 'alā al-facebook [Bar Association: discussions about the judiciary on Facebook are forbidden... al-Sakif [president of the Syrian Bar Association] talks to al-Watan: lawyers to appear before a disciplinary board for their activity on Facebook]. Al-Wațan [online], 1 November. Available from:

http://alwatan.sy/archives/76542 [Access 25 January 2021].

Hamiju, M.M., 2017a. Akkada annah tamm fașl quḍāt natījatan akhțā' mihnīya jasīma... wa-l-abwāb maftūḥa li-‘awdat ayy qāḍin ba'd taswìyat waḍ' ih... wazīr al-'adl l-il-wațan : khuțta li-tațwīr al-qaḍā' tusāhim fĩ taqșīr amad al-taqāọī wataḥsinn waḍ' al-quḍāt wa-ta' dīl qanūn al-sulța al-qaḍā'îya [It's been confirmed: judges dismissed because of major professional errors. The door is open to any judge who wants to return to office after normalising his situation... The Minister of Justice tells al-Watan: There's a plan to reform the justice system to shorten delays and improve on judges' status and the Judicial Authority Law]. Al-Wațan [online], 7 June. Available from: http://alwatan.sy/archives/106888 [Access 25 January 2021].

Hamiju, M.M., 2017b. Al-bakrī : sūrīya hiya min al-duwal al-'ūlā 'arabīyān wa-mișr lā yūjad fīhā illā 'adad qalīl min al-qāḍīyāt... 30 bi-l-mī'a min quḍāt sūrīya hunna nisā' [Al-Bakri: Syria is a progressive Arab country. There are few women judges in Egypt. 30\% of the Syrian judiciary are women]. Al-Wațan [online], 19 July. Available from: http://alwatan.sy/archives/111804 [Access 25 January 2021].

Hejar, O., 2012. Tashkīlāt ḥalab bi-l-mukhtaşar [Court appointments in Aleppo: summary] Facebook post. Hejar Osman [online], 1 November. Available from: https://facebook.com/hejar.osman.1/posts/372926336126512 [No longer online; Access 13 July 2016].

Hilton, D., 2017. Syria's women: Policies and perspectives. The shifting role of women in Syria's economy. Syria Deeply [online], 22 December. Available from: https://deeply.thenewhumanitarian.org/syria/articles/2017/12/22/the-shifting-roleof-women-in-syrias-economy [Access on 25 January 2021].

Hubrecht, J., 2017. Syrie: une justice hors de portée? Esprit [online], 6 (June), 44-56. https://doi.org/10.3917/espri.1706.0044 [Access 21 January 2021]. 
Human Rights Watch, 2013. Syria: Counterterrorism Court used to stifle dissent [online]. Human Rights Watch, 25 June. Available from https://www.hrw.org/news/2013/06/25/syria-counterterrorism-court-used-stifledissent [Access 21 January 2021].

Independent International Commission of Inquiry on the Syrian Arab Republic, 20212011. Independent International Commission of Inquiry on the Syrian Arab Republic: Documentation [online]. United Nations Human Rights Council. Available from: https://www.ohchr.org/EN/HRBodies/HRC/IICISyria/Pages/Documentation.aspx [Access 10 October 2021].

Internal Displacement Monitoring Centre (IDMC), 2020. Global Report on Internal Displacement 2020 [online]. Available from: https://www.internaldisplacement.org/global-report/grid2020/ [Access 13 January 2021].

International Bar Association's Human Rights Institute (IBAHRI), 2011. Human rights lawyers and defenders in Syria: a watershed for the rule of law [online]. Report. July. London: International Bar Association. Available from: https://www.advokatsamfundet.se/globalassets/advokatsamfundet sv/nyheter/s yria report july 2011.pdf [Access 25 January 2021].

Issa, A., 2016. Syria's new media landscape. Independent media born out of war [online]. September. Washington, DC: The Middle East Institute Policy Paper. Available from:

https://www.mei.edu/sites/default/files/publications/PP9 Issa Syrianmedia web 0.pdf [Access 25 January 2021].

Khalaf, I., 2016. Al-ikhbārīya al-sūrīya taltaqī al-qāḍī hishām al-sha'ār ra'îs al-lajna alqaḍ̄āìya al-'ulyā l-il-intikhābāt [Al-Ikhabriya meets with judge Hisham al-Sha'ar, president of the High Judicial Elections Committee]. Al-Ikhbariyah Syria 1, 16 April. https://www.youtube.com/watch? $\mathrm{v}=\mathrm{O}$ P8IPiAgEU\&t=11s [No longer online; access 20 May 2018].

Majlis al-qaḍā' al-sūrī, 2016. Majlis al-qaḍā' al-sūrī, Syrian Judiciary Council [Facebook post] [online], 7 May. Available from:

https://www.facebook.com/mjls.kada2/posts/994880910594380 [Access 10 October 2021].

Martini, N., 2014. Takhațtayna al-shawk li-yalja'na ilā 'ālim al-ḥurrīya. sayīdāt sūrīyāt inshaqaqna 'an ajhizat al-nizāām yarwīna tafāṣīl hịikāyātihinna [They overcame the thorns of life to seek refuge in the land of the free: Syrian women who defected from the state apparatus tell their stories in detail] Sayìdat sūrìy $\bar{a}$ [online], 8, September-October, pp. 16-18; 2 November for Facebook post. Available from: https://www.facebook.com/saiedetsouria/photos/a.467401063366174.1073741828.4 67339570038990/596485173791095/ [Access 27 May 2021].

Mglis kudat, 2012. Bayān tashkīl majlis al-qaḍā' al-sūrī al-ḥurr [Communiqué of the formation of the Free Syrian Judicial Council] [YouTube video]. Mglis kudat [online], 11 December. Available from: https://www.youtube.com/watch?v=kryxuM1Qa6Q [Access 10 October 2021]. 
Office for the Coordination of Humanitarian Affairs (OCHA), 2020. Humanitarian Response Plan Syrian Arab Republic [online], 30 December. Available from https://www.humanitarianresponse.info/en/operations/whole-ofsyria/document/2020-syria-humanitarian-response-plan [Access 13 January 2021].

People's Assembly (majlis al-sha'b), Arab Republic of Syria, 2014. Fawz al-duktūr bashār al-asad bi-mansib ri' āsat al-jumhūrīya 'alā al-aghlabīya al-muṭlaqa min așwāt al-nākhibīn wa-bi-nisbat $88.7 \%$ bi-l-mī' a min 'adad al-aṣwāt al-ṣahịha [Doctor Bashar al-Asad wins the Syrian presidency with an overwhelming majority of $88.7 \%$ of valid votes]. Syrian Parliament (majlis al-sha'b) [online], 5 June.

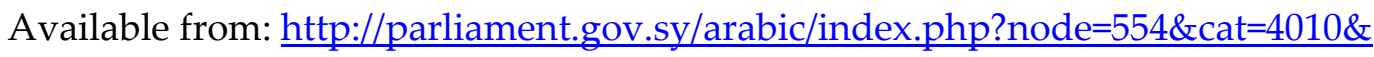
[Access 14 June 2021].

Preston, J., 2011. Syria restores access to Facebook and YouTube. The New York Times [online], 9 February. Available from: https://www.nytimes.com/2011/02/10/world/middleeast/10syria.html [Access 25 January 2021].

Said, A., 2012. Ta'sīs nādin l-il-qaḍā' li-awwal marra fī tārīkh sūrīyā [The foundation of a club for the judiciary for the first time in Syrian history]. Zaman al-Wasl [online], 11 July. Available from: https://www.zamanalwsl.net/news/article/28410 [Access 27 May 2021].

Samir, B., 2016. Al-dawr al-tashrìî̀ al-thānī wājib wațanī wa-istiḥqāq dustūrī [Running for legislature [in the second general elections] is a national duty and constitutional entitlement]. Tishreen News [online], 29 February. Formerly available from: http://new.tishreen.news.sy/?p=12050 [Access 19 July 2016].

Sana in Photos, 2021. Șuwar Sānā [Sana in photos] Facebook post [online], 21 February. Available from:

https://www.facebook.com/Sana.in.Photos/photos/pcb.5106971296043147/5106956 842711259/[Access 10 October 2021].

Shaar, K., and Dasouki, A., 2021. Syria's Constitutional Committee: The Devil in the Detail.MEI@75 [online],6 January. Available from:

https://www.mei.edu/publications/syrias-constitutional-committee-devil-detail [Access 25 January 2021].

Shammas, M., 2017. Al-muhāmī mīshāl shammās: maḥkmat al-irhāb naḥw altashaddud ba'd al-taghayyurāt al-akhīra [Lawyer Michel Shammas: the Counterterrorism Court will become more severe with recent changes]. All4Syria [online], 5 October. Available from:

https://web.archive.org/web/20171008053237/http://www.all4syria.info/Archive/4 46687 [Access 14 June 2021].

Sinjab. L., 2011. Syria opens up to social networks. BBC News [online], 11 February. Available from: https://www.bbc.com/news/world-middle-east-12434079 [Access 25 January 2021].

Syria Now, 2016. Marsūm yunhī taklīf sitta quḍāh min maḥkamat al-irhāb [Legislative decree ends the mandate of six judges of the Counterterrorism Court]. Syria Now [online], 19 September. Available from: 
https://www.facebook.com/SyriaNowOfficial/posts/655006747994220/ [Access 11 June 2021].

Syrian Arab News Agency (SANA), 2015. Al-adl: tanẓìm dā‘ish al-irhābī yaghtāl ghāda jum’a qādī șulh tadmur li-rafḍiha al-'amal ma’h [Justice: The terrorist organisation Daesh murders Ghada Jum'a, a peace court judge in Tadmur for not cooperating with them]. SANA [online], 26 July. Available from: https://www.sana.sy/?p=246094 [Access 25 January 2021].

Syrian Arab News Agency (SANA), 2016. Ḥalab tantakhib mumaththilīhā li-majlis alsha'b ta'kidan 'alā al-intimā' al-wațanī wa-rafụihā li-kull ashkāl al-irhāb [Aleppo elects its representatives of parliament, asserting its national sentiment and rejection of all forms of terrorism]. SANA [online], 13 April. Available from: https://sana.sy/?p=369049 [Access 4 June 2021].

Syrian Arab News Agency (SANA), 2017. Marsūm bi-iḥdāth maḥkamat isti'nāf madanī wa-jazā'î̀ wa-qaḍā' iḥāla li-maḥākim al-nabak wa-yabrūd wa-l-quṭayfa wa-jayrūd [Legislative decree: creation of appeal civil and criminal courts, and Indictment Division in al-Nabak, Yabrud, al-Qutayfa and Jayrud]. SANA [online], 21 December. Available from: https://sana.sy/?p=680322 [Access 9 June 2021].

Syrian Arab News Agency (SANA), 2018. Al-ra'îs al-asad yaṣdur marsūm bi-tasmīyat muhammad jihād al-laḥhām ra'îs li-l-maḥkama al-dustūrīya wa-tasmīyat 'a'ḍā'ihā [President al-Asad issued a decree appointing the members of the Constitutional Court with Muhammad Jihad al-Lahham as its president]. SANA [online], 8 May. Available from: https://www.sana.sy/?p=750229 [Access 31 May 2021].

Syrian Arab Republic, 2011. Consideration of reports submitted by State Parties under article 19 of the Convention: Convention against Torture and Other Cruel, Inhuman or Degrading Treatment or Punishment: comments and follow-up response of the Syrian Arab Republic to the concluding observations of the Committee against Torture (CAT/C/SYR/CO/1/Add.1) [online], 6 September. Available from: https://undocs.org/CAT/C/SYR/CO/1/ADD.1 [Access 20 October 2021].

Syrian Center for Policy Research (SCPR), 2016. Forced dispersion: a demographic report on human status in Syria [online], 8 December. SCPR. Available from: http://scprsyria.org/forced-dispersion-syrian-human-status-the-demographic-report-2016/ [Access 25 January 2021].

Syrian Center for Policy Research (SCPR), 2020. Syria, Justice to Transcend Conflict. Impact of Syrian Conflict Report 2016-2019 [online]. May. SCPR. Available from https://www.scpr-syria.org/justice-to-transcend-conflict/ [Access 15 January 2021].

Syrian Center for Political and Strategic Studies (SCPSS) and Syrian Expert House, 2013. Syria Transition Roadmap [online]. Washington, DC: Syrian Center for Political and Strategic Studies. Available from: http://syrianexperthouse.org/archives/775 [Access 9 June 2021].

Syrian Days, 2016. Tanaqqulāt bi-l-qaḍā' wa-l-mașrī muhāmin 'āmm li-rīf dimashq [Transfers in the judiciary; al-Masri appointed the chief prosecutor in Rural 
Damascus]. Syrian Days [online], 5 October. Available from:

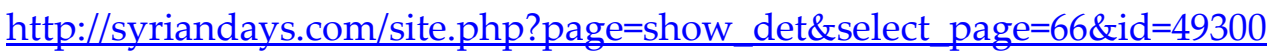

[Access 11 June 2021].

Syrian Network for Human Rights, 2020. The Ninth Annual Report on Enforced

Disappearance in Syria on the International Day of the Victims of Enforced

Disappearance; There is No Political Solution Without the Disappeared [online]. Press release, report, 30 August. Available from

https://sn4hr.org/blog/2020/08/30/55402/ [Access 13 January 2021].

Syrian Revolution Martyr Database, 2016. Martyr counts by gender [online]. Available from:

https://web.archive.org/web/20210123180009/http://syrianshuhada.com/default.as $\mathrm{p}$ ?lang=en\&a=st\&st=1 [Access 25 January 2021].

Syrian Scenes, 2012. Chief Investigator into Al-Qubeir Massacre Defects [YouTube video]. Syrian Scenes [online], 29 July. Available from:

https://www.youtube.com/watch?v=ySLin1CU9YY [20 January 2021].

Television al-Khabar, 2016. Rafụ 272 țalab li-l-tarashshuh li-'uḍīyat majlis al-sha'b fī hums [272 candidacy applications to run for parliament in Homs rejected].

Television al-Khabar [online], 8 March. Available from:

https://www.facebook.com/AlkhabarTS/photos/pb.401200903231386.-

2207520000.1457476079./1167814576570011/?type=3\&theater [Access 4 June 2021].

The Legal Agenda, 2012. Nādī quḍāt sūrīya [Judges' club of Syria]. The Legal Agenda [online], 16 July. Available from: http://www.legal-

agenda.com/article.php?id=1878 [Access 25 January 2021].

Tishreen News, 2012. Awwal qāọīya sūrīya tașaddarat qaws al-ḥukm wa-mā zālat [First woman judge to preside over a court still in office]. Tishreen News, 10 April. http://archive.tishreen.news.sy/tishreen/public/read/255690 [No longer online; access 14 June 2018].

Trochev, A., and Ellett, R., 2014. Judges and their allies. Rethinking judicial autonomy through the prism of off-bench resistance. Journal of Law and Courts [online], 2(1), 67-91. Available from: https://doi.org/10.1086/674528 [Access 14 October 2021].

Ugarit News - Syria, 2012a. Ūghārīt al-inshiqāq al-awwal fī sūrīyā inshiqāq al-qāḍī Ṭalāl Ḥūshān ra'îs niyāba Maḥarda 2572012 [Ugarit, The first resignation in Syria: resignation of Talal Hushan, prosecutor of Maharda 257 2012] [YouTube video]. Ugarit News - Syria [online], 25 July. Available from:

https://www.youtube.com/watch? $\mathrm{v}=\mathrm{k} 3 \mathrm{RXdKs43Hk}$ [Access 10 October 2021].

Ugarit News - Syria, 2012b. Ūghārīt Idlib inshiqāq jamā’̄î li-qu ḍāt al-qasr al-'adlī 912 Idlib [Ugarit Idlib: group resignation of judges and prosecutors of the Idlib courthouse on 9 December] [YouTube video]. Ugarit News - Syria [online], 9 December. Available from: https://www.youtube.com/watch?v=W2Vortb1a28 [Access 10 October 2021].

UN Committee on the Elimination of Discrimination against Women (UN CEDAW), 2012. Consideration of reports submitted by States Parties under Article 18 of the Convention on the elimination of all forms of discrimination against women: second and 
third periodic reports of States Parties, Syria (CEDAW/C/SYR/2) [online], 24 October. Available from:

https://tbinternet.ohchr.org/ layouts/treatybodyexternal/Download.aspx?symbol no=CEDAW\%2FC\%2FSYR $\% 2 F 2 \& L a n g=e n$ [Access 25 January 2021].

UN Human Rights Council, 2014. [7 ${ }^{\text {th }}$ Report of the Independent International Commission of Inquiry [IICI] on the Syrian Arab Republic (A/HRC/25/65) [online], 12 February.

Available from:

https://www.ohchr.org/EN/HRBodies/HRC/IICISyria/Pages/Documentation.aspx [Access 16 January 2021].

UN Office of the High Commissioner for Human Rights, 2021. Oral Update on the Extent of Conflict-Related Deaths in the Syrian Arab Republic. Background Note on the Statistical Analysis [online], 24 September. Available from:

https://www.ohchr.org/Documents/Countries/SY/BackgroundTechnicalNote Syri a.pdf [Access 28 October 2021].

UN Security Council, 2019. Letter dated 26 September 2019 from the Secretary-General addressed to the President of the Security Council (S/2019/775) [online], 26 September. Available from:

https://reliefweb.int/sites/reliefweb.int/files/resources/S 2019775 E.pdf [Access 10 October 2021].

Violations Documentation Center in Syria (VDC), 2015. Special report on CounterTerrorism Law No. 19 and the Counter-Terrorism Court in Syria. Counter-Terrorism Court: A tool for war crimes [online], April. Available from: http://www.vdcsy.info/pdf/reports/1430186775-English.pdf [Access on 14 June 2021].

Yahiamahmod123, 2017. Majlis al-qaḍā' al-'a'lā yașdur al-qarār bi-sha'n al-qaḍiya alta' dībīya ḍidd al-qāộ̄ Sīdrā Hanafī mu'linān 'adam mas'ūlīyatihā [High Judicial Council publishes a decision regarding the disciplinary action against Judge Sidra Hanafi stating she was innocent], [Facebook post]. Kull ma yahumm al-qud̄at wa-lmuhāmūn, All matters concerning judges and lawyers [online], 12 October. Available from: https://www.facebook.com/yahiamahmod123/posts/1584005651683701 [Access 10 October 2021].

Zaman al-Wasl, 2015. Ba'd anna jama' mi'āt al-malāyīn min ahālī almu'taqalīn...taghyīr ra'îs maḥkamat al-irhāb al-ūlā wa-iḥdāth maḥkamat ukhrā [After having collected millions of Syrian pounds from the families of detainees... the president of the Counterterrorism Court was changed and another chamber was created]. Zaman al-Wasl [online], 1 May. Available from https://www.zamanalwsl.net/news/article/60323 [Access 14 June 2021].

Legal sources

Counterterrorism Court Law No. 22 of 26 July 2012 [online]. Syrian Parliament (majlis $a l$-sha'b). Available from:

http://www.parliament.gov.sy/arabic/index.php?node=201\&nid=4304\&ref=tree\& [Access 10 October 2021]. 
Counterterrorism Law No. 19 of 2 July 2012 [online]. Available from: https://cyrilla.org/fr/document/u8abg01c5iugdwgfbx5yiudi?page=1 [Access 10 October 2021].

Decree No. 161 of 21 April 2011 [online]. Syrian Parliament (majlis al-sha'b). Available from:

https://www.parliament.gov.sy/arabic/index.php?node=201\&nid=4444\&ref=tree\& [Access 9 June 2021].

General Elections Law No. 5 of 17 March 2014 [online]. Syrian Parliament (majlis alsha'b). Available from:

https://www.parliament.gov.sy/arabic/index.php?node=5518\&cat=459\& [Access 3 June 2021].

Judicial Authority Law No. 98 of 15 November 1961 with amendments [online]. Syrian Parliament (majlis al-sha`b). Available from:

http://www.parliament.gov.sy/arabic/index.php?node=5576\&cat=16043 [Access 10 October 2021].

Legislative Decree No. 112 of 13 March 1950 [online]. Syrian Parliament (majlis al-sha'b). Available from:

http://www.parliament.gov.sy/arabic/index.php?node=5556\&cat=11810 [Access 4 October 2021].

Legislative Decree No. 51 of 22 December 1962 [online]. Damascus Bar Association. Available from:

http://www.damascusbar.org/AlMuntada/showthread.php?t=806 [Access 29 Septembre 2021].

Legislative Decree No. 47 of 28 March 1968 [online]. The Syrian Human Rights Committee. Available from: https://www.shrc.org/?p=7445 [Access 29 September 2021].

Legislative Decree No. 14 of 15 January 1969.

Legislative Decree No. 64 of 30 September 2008 [online]. Syrian Parliament (majlis alsha'b). Available from:

http://www.parliament.gov.sy/arabic/index.php?node $=5585 \&$ nid $=16268 \&$ First $=0$ $\underline{\text { Last }}=3 \&$ CurrentPage $=0 \& \mathrm{mid}=\&$ refBack $=$ [Access 4 October 2021].

Legislative Decree No. 53 of 21 April 2011 [online]. Syrian Parliament (majlis al-sha'b). Available from:

https://www.parliament.gov.sy/arabic/index.php?node $=201 \&$ nid $=4441 \&$ ref $=$ tree\& [Access 9 June 2021].

Legislative Decree No. 54 of 21 April 2011. Syrian Parliament (majlis al-sha'b). Available from: https://www.parliament.gov.sy/arabic/index.php?node $=55151 \&$ cat $=4442$ [Access 9 June 2021].

Legislative Decree No. 55 of 21 April 2011 [online]. Syrian Parliament (majlis al-sha'b). Available from:

https://www.parliament.gov.sy/arabic/index.php?node=201\&nid=4443\&ref=tree\& [Access 9 June 2021]. 
Legislative Decree No. 101 of 3 August 2011 [online]. Syrian Parliament (majlis al-sha'b). Available from:

https://www.parliament.gov.sy/arabic/index.php?node=5516\&cat=4397 [Access 3 June 2021].

Legislative Decree No. 54 of 4 August 2013 [online]. Syrian Parliament (majlis al-sha'b). Available from:

http://www.parliament.gov.sy/arabic/index.php?node=201\&nid=4254\&ref=tree\& [Access 29 September 2021].

Decisions and decrees of judicial appointments and creation of courts

Decision No. 57/L of 17 January 2010 [online], Abu al-Zayn 2010.

Decision No. 2194L of 7 August 2011 [online]. Damascus Bar Association. Available from: http://www.damascusbar.org/arabic/court_rief2011.pdf [Access 9 June 2021].

Decision No. 2195L of 7 August 2011 [online]. Damascus Bar Association. Available from: http://www.damascusbar.org/arabic/court2011.pdf [Access 9 June 2021].

Decision No. 1332L of 20 May 2012 [online]. Damascus Bar Association. Available from: http://www.damascusbar.org/arabic/judidical sys/jud str new 2012.htm [Access 9 June 2021].

Decision No. 2442L of 30 October 2012 [no longer available from the Damascus Bar Association].

Decision No. 3891L of 26 July 2015 [online]. Available from: https://m.facebook.com/yahiamahmod123/posts/868323426585264 [Access 9 June 2021].

Decision No. 3681L of 20 April 2017 [online]. Ministry of Justice of Syria. Available from:

https://web.archive.org/web/20170613232357/http://www.moj.gov.sy/images/2017 Qrarat $/ 3681 \%$ D9\%84.PDF [Access 9 June 2021].

Decision No. 4951L of 3 August 2017 [online]. Available from: https://www.facebook.com/LawyerAgenda/posts/1798303050479697 [Access 11 June 2021].

Decision No. 358 of 21 December 2017 [online], SANA 2017.

Decision No. 2497L of 10 June 2018 [online]. Available from: https://www.facebook.com/MOI.SYR/photos/pcb.1817571658549684/18175708018 83103/ [Access 9 June 2021].

Decision No. 1134/L of 5 May 2020 [online]. Available from: https://www.facebook.com/MOJ.SYR/photos/pcb.2294334974206681/22943347442 06704/ [Access 9 June 2021].

Decision No. 648L of 18 February 2021 [online]. Available from: https://www.facebook.com/MOJ.SYR/photos/pcb.2511802655793244/25118025124 59925/ [Access 12 June 2021]. 
Decree No. 173 of 22 May 2012 [online], Abu al-Zayn 2012.

Decree No. 317 of 29 August 2012 [online], All4Syria 2012.

Decree No. 133 of 24 April 2014 [online]. High Elections Committee. Available from:

https://hce.gov.sy/index.php?option=com content\&view $=$ category\&layout=blog\&

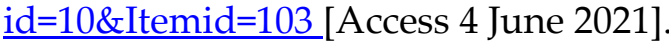

Decree No. 290 of 18 September 2016 [online], Syrian Now 2016 and Syrian Days 2016.

Decree No. 287 of 3 October 2017 [online], Ahmad 2017.

Decree No. 165 of 8 May 2018 [online], SANA 2018.

Decree No. 117 of 3 April 2019 [online]. Available from:

https://www.facebook.com/hashtagsyria.sy/posts/2275828082639443 [Access 2 June 2019].

Decree No. 69 of 20 February 2020 [online]. Available from:

https://www.facebook.com/MOJ.SYR/photos/pcb.2243086489331530/22430864059 98205/ [Access 13 June 2021]. 